\title{
$\gamma$-Glutamyl hydrolase modulation and folate influence chemosensitivity of cancer cells to 5-fluorouracil and methotrexate
}

\author{
S-E Kim ${ }^{1,2}$, P D Cole ${ }^{3}$, R C Cho ${ }^{1}$, A Ly ${ }^{1}$, L Ishiguro ${ }^{1,2}$, K-J Sohn ${ }^{2,4}$, R Croxford ${ }^{5}$, B A Kamen ${ }^{6,}$ and Y-I Kim ${ }^{*, 1,2,4,7}$ \\ ${ }^{1}$ Department of Nutritional Sciences, University of Toronto, Toronto, Ontario, Canada M5S 1A8; ${ }^{2}$ Keenan Research Center, Li Ka \\ Shing Knowledge Institute at St. Michael's Hospital, Toronto, Ontario, Canada M5B 1W8; ${ }^{3}$ Department of Pediatrics, \\ Albert Einstein College of Medicine, Bronx, New York 10467, USA; ${ }^{4}$ Department of Medicine, University of Toronto, Toronto, \\ Ontario, Canada M5S 1A8; ${ }^{5}$ Statistical Consultant Toronto, Ontario, Canada M4E 3K7; ${ }^{6}$ Department of Pediatrics and \\ Pharmacology, Robert Wood Johnson Medical School, University of Medicine and Dentistry of New Jersey, New Brunswick, New \\ Jersey 08901, USA and 'Division of Gastroenterology, Department of Medicine, St. Michael's Hospital, Toronto, Ontario, Canada \\ M5B 1W8
}

Background: $\gamma$-Glutamyl hydrolase (GGH) regulates intracellular folate and antifolates for optimal nucleotide biosynthesis and antifolate-induced cytotoxicity, respectively. The modulation of GGH may therefore affect chemosensitivity of cancer cells, and exogenous folate levels may further modify this effect.

Methods: We generated a novel model of GGH modulation in human HCT116 and MDA-MB-435 cancer cells and investigated the effect of GGH modulation on chemosensitivity to 5-fluorouracil (5FU) and methotrexate (MTX) at different folate concentrations in vitro and in vivo.

Results: Overexpression of GGH significantly decreased chemosensitivity of MDA-MB-435 cells to 5FU and MTX at all folate concentrations as expected. In contrast, in $\mathrm{HCT} 116$ cells this predicted effect was observed only at very high folate concentration, and as the folate concentration decreased this effect became null or paradoxically increased. This in vitro observation was confirmed in vivo. Inhibition of GGH significantly increased chemosensitivity of both cancer cells to $5 F U$ at all folate concentrations. Unexpectedly, GGH inhibition significantly decreased chemosensitivity of both cancer cells to MTX at all folate concentrations. In both GGH modulation systems and cell lines, the magnitude of chemosensitivity effect incrementally increased as folate concentration increased.

Conclusion: Modulation of GGH affects chemosensitivity of cancer cells to 5FU and MTX, and exogenous folate levels can further modify the effects.

Folate has an essential role in DNA synthesis involved in thymidylate and purine biosynthesis as an important mediator of one-carbon transfer reactions (Shane, 2010). In neoplastic cells, folate depletion and disrupted folate metabolism cause ineffective
DNA synthesis, resulting in inhibition of tumour growth (Kamen, 1997). This has been the basis for cancer chemotherapy using antifolates and 5-fluorouracil (5FU; Kamen, 1997). Folate is retained intracellularly by folylpolyglutamate synthase (FPGS)-induced

*Correspondence: Dr Y-I Kim; E-mail: youngin.kim@utoronto.ca

Presented in part at the 2011 American Association for Cancer Research Meeting and published in abstract form in Proceedings of the American Association for Cancer Research 52: abstract 1668 and 1680, 2011.

Deceased.

Revised 27 August 2013; accepted 28 August 2013; published online 17 September 2013

(c) 2013 Cancer Research UK. All rights reserved 0007-0920/13 
polyglutamylation, whereas $\gamma$-glutamyl hydrolase (GGH) removes the $\gamma$-polyglutamate tails attached to folate to produce the monoglutamate form and facilitate the export out of cells (Shane, 2010). Polyglutamylated folates are better retained in cells and are better substrates than monoglutamates for intracellular folate-dependent enzymes (Moran, 1999).

As with folate, polyglutamylated antifolates, such as methotrexate (MTX), are retained for a longer duration in cells, thereby increasing their cytotoxicity by extending the length of exposure (Kamen, 1997; Moran, 1999). Furthermore, polyglutamylated antifolates generally have a higher affinity for and, hence, inhibit their target folate-dependent enzymes in thymidylate and purine biosynthesis to a greater extent than the monoglutamate form (Kamen, 1997; Moran, 1999).

Changes in polyglutamylation of a specific intracellular folate cofactor may also affect the sensitivity of tumour cells to other chemotherapeutic agents, such as 5FU, not typically considered as antifolate. 5-Fluorouracil is a prototype of pyrimidine antagonists with several cytotoxic mechanisms, including incorporation of its metabolites as false precursor into DNA and RNA, resulting in DNA instability and interfering with RNA processing and function, respectively (Longley et al, 2003). Another cytotoxic mechanism of $5 \mathrm{FU}$ is the formation of a ternary complex involving a metabolite of 5FU (FdUMP; 5-fluoro-2-deoxyuridine-5-monophosphate), thymidylate synthase (TS) and 5,10-methylenetetrahydrofolate (5,10-methyleneTHF), thereby inhibiting TS activity with consequent suppression of DNA synthesis (Longley et al, 2003). Leucovorin (LV; 5-formylTHF), a precursor for 5,10-methyleneTHF, potentiates the cytotoxic effect of $5 \mathrm{FU}$ by stabilising this inhibitory ternary complex, and is therefore routinely administered with 5FU in cancer chemotherapy in order to increase the intracellular pool of 5,10-methyleneTHF (Longley et al, 2003). 5,10 -Methylenetetrahydrofolate with longer chain length polyglutamates is better retained intracellularly and is more efficient in the formation and stabilisation of this inhibitory ternary complex compared with shorter chain polyglutamates (Radparvar et al, 1989). Therefore, modulation of 5,10-methyleneTHF polyglutamylation may affect chemosensitivity of cancer cells to 5FU.

The effects of differences in FPGS activity and of specific FPGS modulation on drug resistance of and chemosensitivity to MTX and other antifolates (Pizzorno et al, 1988; McCloskey et al, 1991; Roy et al, 1997; Aghi et al, 1999; Zhao et al, 2000; Mauritz et al, 2002; Liani et al, 2003), and 5FU (Romanini et al, 1991; Wang et al, 1993; Cheradame et al, 1997) have been extensively studied. In general, high FPGS activity or upregulation appears to enhance chemosensitivity of cancer cells to MTX, other antifolates and 5FU, whereas low FPGS activity or downregulation seems to be a mechanism of resistance to MTX and other antifolates, as well as $5 \mathrm{FU}$.

In contrast, the role of GGH modulation in influencing chemosensitivity of cancer cells to antifolates and 5FU has not yet been clearly established (Galivan et al, 2000; Panetta et al, 2002a,b; Schneider and Ryan, 2006). Increased GGH activity was identified as the mechanism of antifolate resistance in rat hepatoma cells (Rhee et al, 1993; Yao et al, 1995), human sarcoma cells (Li et al, 1993) and human leukaemia cells (Pizzorno et al, 1995). However, ectopic overexpression of GGH after transfection of MCF7 breast cancer and HT1080 fibrosarcoma cells did not confer MTX resistance (Cole et al, 2001). Pharmacologic GGH inhibition was observed to enhance the sensitivity of human sarcoma (Waltham et al, 1997) and breast cancer cells (Alabaster et al, 1981; Kennedy et al, 1983) to MTX. Inhibition of GGH induced by small-interfering RNA (siRNA) in human DLD-1 colon cancer cells enhanced sensitivity to 5FU (Sakamoto et al, 2008).

$\gamma$-Glutamyl hydrolase may have an important role in modulating drug resistance and chemosensitivity of cancer cells to antifolates and 5FU by inducing changes in polyglutamylation of antifolates and a specific target intracellular folate cofactor (e.g., 5,10-methyleneTHF for 5FU), respectively. However, GGH modulation affects polyglutamylation of not only antifolates and specific target intracellular folate cofactors but also of all other intracellular folate cofactors. Modulation of GGH also affects total intracellular folate concentration, which is an important determinant of the cytotoxic effects of antifolates and 5FU (Kamen, 1997; Backus et al, 2000; Zhao et al, 2001). Therefore, the GGH modulation-induced changes in intracellular folate concentrations and folylpolyglutamylation may counterbalance the effects of the GGH modulation-induced changes in polyglutamylation of antifolates and specific 5,10-methyleneTHF. We have previously demonstrated this complex interaction in an in vitro model of FPGS overexpression and inhibition (Sohn et al, 2004b; Cho et al, 2007).

In the present study, we generated an in vitro model of GGH modulation in human HCT116 colon and MDA-MB-435 breast cancer cells, and determined the effects of GGH modulation on chemosensitivity to 5FU and MTX. We also determined whether exogenous folate concentrations further influence the effects of GGH modulation on the chemosensitivity to 5FU and MTX in vitro and in vivo.

\section{MATERIALS AND METHODS}

Cell line and culture. Human colon adenocarcinoma HCT116 and breast adenocarcinoma MDA-MB-435 cells were purchased from the American Type Culture Collection (Manassas, VA, USA). For experiments pertaining to the generation and characterisation of an in vitro model of GGH modulation, both cells were grown in standard RPMI-1640 medium (Invitrogen, Gaithersburg, MD, USA) containing $2.3 \mu \mathrm{moll}^{-1}$ folic acid. Growth medium was supplemented with $10 \%$ dialysed fetal bovine serum (Invitrogen),

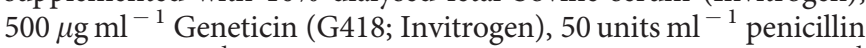
with $50 \mu \mathrm{g} \mathrm{ml}^{-1}$ streptomycin (Invitrogen) and $0.25 \mu \mathrm{g} \mathrm{ml}^{-1}$ fungizone amphotericin B (Invitrogen). Cultures were maintained at $37^{\circ} \mathrm{C}$ in $5 \% \mathrm{CO}_{2}$. For in vitro chemosensitivity experiments, both cells were grown in standard RPMI-1640 medium containing $2.3 \mu \mathrm{moll}^{-1}$ folic acid or in RPMI-1640 free of folic acid supplemented with either 50 or $100 \mathrm{nmoll}^{-1} 5$-methyltetrahydrofolate (5-MTHF; Schircks Laboratories, Jona, Switzerland).

Folic acid is the fully oxidised monoglutamyl synthetic form of folate used in supplements and fortified foods (Shane, 2010). Folic acid is highly stable in contrast to naturally occurring folates, which are very unstable and rapidly lose their activity in foods and are easily oxidised under low $\mathrm{pH}$ (Shane, 2010). Folic acid is not found in nature nor is it a normal metabolite. It must be reduced and methylated to 5-MTHF before it can enter the folate cycle (Shane, 2010). Nevertheless, because of its stability folic acid is the usual form of folate used in culture media and $2.3 \mu \mathrm{moll}^{-1}$ folic acid, albeit a supraphysiologically high level considering that median plasma/serum concentrations of unmetabolised folic acid range from 0.50 to $1.2 \mathrm{nmoll}^{-1}$ in North America in the post-folic acid fortification era depending on folic acid supplement use (Kalmbach et al, 2008; Bailey et al, 2010), is the standard amount used in most culture media. 5-Methyltetrahydrofolate is the predominant form of folate found in blood (Shane, 2010) and was therefore selected to represent nutritionally and physiologically relevant form of folate. 5-Methyltetrahydrofolate $\left(50 \mathrm{nmoll}^{-1}\right)$ in culture medium was selected to reflect a likely average serum folate concentration in the North American population in the post-folic acid fortification era. Large population-based surveys in North America post fortification have reported mean serum folate concentrations of 41-42 (Bailey et al, 2010; Pfeiffer et al, 2012) 
and $\sim 30 \mathrm{nmoll}^{-1}$ higher serum folate concentrations in supplemental users (mostly from multivitamin containing $0.4 \mathrm{mg}$ folic acid) compared with non-users (Pfeiffer et al, 2012). One study has reported a mean serum 5-MTHF concentration of $49.3 \mathrm{nmoll}^{-1}$ in the North American population post fortification (Bailey et al, 2010). In these surveys, 75th and 95th percentile values of serum folate concentrations were $\sim 60$ and $105 \mathrm{nmoll}^{-1}$, respectively, largely owing to folic acid supplement use (Pfeiffer et al, 2012). In human clinical trials, folic acid supplementation at $0.8-1.0 \mathrm{mg}$ per day increased plasma/serum folate concentrations to $\sim 80$ $100 \mathrm{nmoll}^{-1}$ (Bruce et al, 2005; Bonaa et al, 2006; Ebbing et al, 2008). Therefore, in the present study we selected 50 and $100 \mathrm{nmoll}^{-1} 5$-MTHF to represent likely average and high serum folate concentrations, respectively, in the North American population in the post-fortification era.

Construction and transfection of GGH expression vectors. The full-length human GGH cDNA (1.2 kb; GeneBank accession No. U55206; Yao et al, 1996) was subcloned into the Not1 site of the eukaryotic expression vector pIRESneo (Clontech, Palo Alto, CA, USA) in the sense orientation to generate the sense GGH expression vector as described (Sohn et al, 2004a,b; Cho et al, 2007). The GGH-targeted siRNA was designed according to the manufacturer's protocol and ligated into the vector between the $B a m \mathrm{H} 1$ and HindIII restriction sites of the pSilencer neo siRNA expression vector (Ambion, Austin, TX, USA) as described (Cho et al, 2007). The oligonucleotides were designed encoding the desired siRNA strand: $5^{\prime}$-GTACTTGGAGTCTGCAGGT- $3^{\prime}$ (forward) and $5^{\prime}$-ACCTGCAGACTCCAAGTAC-3' (reverse), and $5^{\prime}$-ACCTGCAGACTCCAAGTAC-3' (forward) and 5'-GTACTTG GAGTCTGCAGGT- $3^{\prime}$ (reverse). The correct integration, orientation and sequence of the sense GGH cDNA and GGH-targeted siRNA were confirmed by predicted fragment sizes after multiple restriction enzyme digestions and DNA sequencing.

The pIRESneo vector containing sense cDNA and the pSilencer vector containing GGH-targeted siRNA were stably transfected into HCT116 and MDA-MB-435 cells using Lipofectin (Invitrogen) according to the manufacturer's protocol. In separate transfections, both cell lines were stably transfected with empty pIRESneo and pSilencer vectors as corresponding controls expressing endogenous GGH. Transfected cells were incubated with $500 \mu \mathrm{g} \mathrm{ml}^{-1}$ of neomycin (Invitrogen) to select for cells that expressed the various constructs. After a population of cells was selected, individual clonal cell lines were isolated and expanded. Cells were maintained in complete medium supplemented with $500 \mu \mathrm{g} \mathrm{ml}^{-1}$ of neomycin. Over 10 clones expressing the sense GGH cDNA, GGH-targeted siRNA and empty vectors were screened at random, and two independent clones of each construct were selected for further analysis. Data from three experiments using two independent clones of each construct were similar and, thus, the data from one experiment are presented. All analyses were done in triplicate.

Western blot analysis. GGH and dihydrofolate reductase (DHFR) protein expression was determined by standard western analysis as described (Sohn et al, 2004a; Cho et al, 2007), using a rabbit polyclonal antibody raised against human GGH (SDI, Newark, DE, USA) at a dilution of 1:1000 and against human DHFR (Sigma, Oakville, ON, Canada) at a dilution of 1:3000. To confirm that the proteins were loaded equally, the membranes were stripped and reprobed with a mouse monoclonal antibody raised against human $\beta$-actin (Sigma) at a dilution of 1:3000. All western analyses were repeated using three different cell lysates. Densitometry of bands were determined using the public domain ImageJ (version 1.38) from the National Institute of Health available on the Internet at http://rsbweb.nih.gov/ij.
GGH, TS and DHFR enzyme activity assays. The activity of GGH was determined by incubating protein in cell lysate with MTX-glu ${ }_{4}$ as substrate and measuring MTX and its polyglutamates using HPLC as described (Panetta et al, 2002a; Cho et al, 2007). The catalytic activity of TS was determined by the ${ }^{3} \mathrm{H}$ release that occurred during the conversion of $\left[5-{ }^{3} \mathrm{H}\right]-\mathrm{dUMP}$ to dTMP (deoxythymidine-5-monophosphate) as described (Peters et al, 1987). The catalytic activity of DHFR was determined using the DHFR assay kit (Sigma) as per the manufacturer's protocol. The assay is based on the ability of DHFR to catalyse the reversible NADPH-dependent reduction of DHF to THF. Enzyme assays were performed in triplicate, and three replicate experiments were performed.

Intracellular folate concentrations and glutamate chain lengths. Intracellular folate concentrations for conjugase-treated (which allows the measurement of total intracellular folate concentration, including short- and long-chain folylpolyglutamates) and -untreated (which allows the determination of short-chain folylpolyglutamates) samples were determined by a standard microbiological assay to determine the extent of polyglutamylation as described (Sohn et al, 2004b; Cho et al, 2007). All analyses were performed in triplicate, and three replicate experiments were performed.

Doubling time calculation. Cells (8000 per well) were plated in a 96-well flat-bottom plate and grown either in RPMI-1640 medium containing $2.3 \mu \mathrm{moll}^{-1}$ folic acid or in RPMI-1640 free of folic acid supplemented with either 50 or $100 \mathrm{nmoll}^{-1} 5$-MTHF for $72 \mathrm{~h}$. The cell population was determined using the sulphorhodamine B (SRB) optical density (OD) measurement assay (Sohn et al, 2004a,b; Cho et al, 2007). The growth rate constant $k$ was derived using the equation $N / N_{0}=e^{\mathrm{kt}}$, where $N_{0}$ is the OD of cells at time zero and $N$ is the OD of cells at $72 \mathrm{~h}$. The same equation was used to calculate doubling time $t$, by setting $N / N_{0}=2$. All analyses were performed in triplicate, and three replicate experiments were performed.

In vitro chemosensitivity assay. In vitro chemosensitivity was determined using a modification of the SRB protein assay as described (Skehan et al, 1990; Sohn et al, 2004a,b; Cho et al, 2007). Briefly, 8000 cells per $100 \mu$ l RPMI-1640 medium per well were seeded in triplicate in 96-well flat-bottom plates. After $24 \mathrm{~h}$, an additional $100 \mu$ l of RPMI-1640 medium containing 5FU (InvivoGen, San Diego, CA, USA) and LV (Sigma) or MTX (Sigma) were added, and cells were cultured for an additional $72 \mathrm{~h}$. Medium folate concentrations were $2.3 \mu \mathrm{moll}^{-1}$ folic acid, or 50 or $100 \mathrm{nmoll}^{-1} 5$-MTHF. In both cell lines, the concentration of $5 \mathrm{FU}$ ranged from $1.5 \times 10^{-6}$ to $25 \times 10^{-6} \mathrm{M}$, whereas the concentration of $\mathrm{LV}$ was held constant at $5 \times 10^{-6} \mathrm{M}$. The concentration range of MTX was $0.5-5 \times 10^{-8}$ and $1.5-$ $6 \times 10^{-8} \mathrm{M}$ in HCT116 and MDA-MB-435 cells, respectively. After $72 \mathrm{~h}$, cells were fixed with trichloroacetic acid and stained with SRB protein dye. The dye was solubilised and the OD of the solution measured at $595 \mathrm{~nm}$. The results were expressed as the percentage of cell survival on the basis of the difference between the OD at the start and end of drug exposure, according to the formula (Peters et al, 1993):

Survival $(\%)=\left[\left(\mathrm{OD}_{\text {drug }} / \mathrm{OD}_{\text {start drug exposure }}\right)-1\right] /\left[\left(\mathrm{OD}_{\mathrm{no}}\right.\right.$ drug $/$ $\left.\left.\mathrm{OD}_{\text {start drug exposure }}\right)-1\right] \times 100$.

$\mathrm{IC}_{50}$ values (i.e., the drug concentration that corresponded to a reduction in cell survival of $50 \%$ compared with survival of untreated control cells) were calculated from plots of drug concentration vs proportion of cells that survived. All analyses were performed in sextuplet, and at least three replicate experiments were performed for all drug treatments. 
In vivo chemosensitivity. The protocol was approved by the Animal Care Committee of the University of Toronto. Twenty 6-week-old male BALB/c nu/nu mice (Charles River, Wilmington, MA, USA) received subcutaneous injections in each flank of HCT116 colon cancer cells expressing endogenous GGH or the sense GGH $\left(1 \times 10^{6}\right.$ cells per site per mouse $)$ in $100 \mu \mathrm{l}$ of serumfree RPMI-1640 medium after acclimatisation to an amino aciddefined control diet containing $2 \mathrm{mg}$ folic acid per $\mathrm{kg}$ diet for a week. When xenografts reached a volume of $80-200 \mathrm{~mm}^{3}$, mice were randomly assigned to receive the control or folic acidsupplemented ( $8 \mathrm{mg}$ per $\mathrm{kg}$ diet) diet ( $n=10$ per dietary group). Within each dietary group, mice received $5 \mathrm{FU}+\mathrm{LV}$ or $0.9 \% \mathrm{NaCl}$ intraperitoneally ( $n=5$ per treatment group). 5-Fluorouracil (20 $\mathrm{mg} \mathrm{kg}^{-1}$ per day) dissolved in $100 \mu \mathrm{l}$ of $0.9 \% \mathrm{NaCl}$ was administered by intraperitoneal injection for five consecutive days for a week as described (Sohn et al, 2004a). Leucovorin (1 $\mathrm{mg} \mathrm{kg}^{-1}$ per day) dissolved in $100 \mu \mathrm{l}$ of $0.9 \% \mathrm{NaCl}$ was administered $1 \mathrm{~h}$ before 5FU administration by intraperitoneal injection (Sohn et al, 2004a). Therefore, there were four groups of mice $(n=5$ per group): (i) treated with $0.9 \% \mathrm{NaCl}$ and on the control diet; (ii) treated with $5 \mathrm{FU}+\mathrm{LV}$ and on the control diet; (iii) treated with $0.9 \% \mathrm{NaCl}$ and on the folic acid-supplemented diet; and (iv) treated with $5 \mathrm{FU}+\mathrm{LV}$ and on the folic acid-supplemented diet.

The selected dose of 5FU and LV was determined based on the Mayo Clinic regimen $\left(20 \mathrm{mg} \mathrm{m}^{-2} \mathrm{LV} \quad\left(0.7 \mathrm{mg} \mathrm{kg}^{-1}\right)+425\right.$ $\mathrm{mg} \mathrm{m}^{-2}$ 5FU (14 $\mathrm{mg} \mathrm{kg}^{-1}$ ); Buroker et al, 1994). Amino aciddefined diets containing different levels of folic acid constitute a standard method of providing supplemental dietary folate in rodents (Song et al, 2000). The control diet containing $2 \mathrm{mg}$ folic acid per $\mathrm{kg}$ diet $(0.5-1 \mathrm{mg}$ of folic acid in $2000 \mathrm{kcal})$ is accepted as the basal dietary requirement for rodents (Song et al, 2000) and was selected to parallel the recommended daily allowance for folate in humans $(0.4 \mathrm{mg}$ dietary folate equivalent in humans consuming a daily average of $2000 \mathrm{kcal})$. The supplemental level of folic acid at $8 \mathrm{mg}$ per $\mathrm{kg}$ diet approximates a total folate intake from fortified foods and daily supplement use of $1 \mathrm{mg}$ folic acid and represents approximately four times the recommended daily allowance for folate in humans (i.e., $1.6 \mathrm{mg}$ per day). The detailed composition of the diets has been published previously (Song et al, 2000). Sterilised diets and water were provided ad libitum. Food intake and body weights were recorded twice a week.

The tumours were measured with a digital caliper twice a week. The estimated tumour volume $(\mathrm{V})$ was calculated based on the formula $\mathrm{W}^{2} \times \mathrm{L} \times 0.5$, where $\mathrm{W}$ represents the largest tumour diameter in centimetres and $\mathrm{L}$ represents the next largest tumour diameter (Bras-Goncalves et al, 2000). The individual relative tumour volume (RTV) was calculated as $V_{\mathrm{x}} / V_{1}$, where $V_{\mathrm{x}}$ is the volume in cubic millimetres at a given time and $V_{1}$ is the volume at the start of treatment. Results are expressed as the mean daily per cent change in tumour volume for each group of mice.

Plasma folate concentrations. At necropsy, blood was collected for plasma folate assay. Plasma folate concentrations were determined by a standard microbiological microtitre plate assay (Sie et al, 2011).

Statistical analysis. For continuous variables, comparisons between cells expressing the sense GGH (Sense) and controls (Control-S), and between cells transfected with the GGH-targeted siRNA (siRNA) and controls (Control-si) were determined using the Student's $t$-test. For the in vitro chemosensitivity analyses, plots of percentage of survival versus dose demonstrated $S$-shaped curves and, therefore, the $\operatorname{logit}$ transformation $(\operatorname{logit}(\mathrm{p})=\ln (\mathrm{p} /$ $(1-p)))$ was used. Ordinary least squares regression was used to model the effect of $\log ($ dose $)$ of chemotherapy and cell type on the logit transformed proportion of cells that survived at each dose. The interaction between cell type and $\log ($ dose) was included in the model to test the hypothesis that the cell types were differentially sensitive to chemotherapy. $\mathrm{IC}_{50}$ doses and their $95 \%$ confidence intervals (CIs) were calculated on the log scale from the regression results as described (Draper and Smith, 1981), and then backtransformed to the original scale for reporting.

For the in vivo chemosensitivity analysis, the dependent variable was tumour volume, which was log-transformed due to its skewed distribution. A generalised linear regression was used to account for the fact that each mouse had been injected with two different types of cells, and, in addition, each mouse was measured repeatedly over time. The resulting slopes estimate the change in $\log$ (volume) per day and, when back-transformed, estimate the growth rate per day. The effect of diet, treatment and/or cell types on rate of growth was included due to a significant interaction between the effect of time and the effect of one or more of the other three factors. Plasma folate concentrations were analysed by twoway ANOVA analysis, with diet and treatment as the independent variables. For all analyses, results were considered statistically significant if two-tailed $P$-values were $<0.05$. Analyses were performed using SPSS Statistics 17.0 (IBM SPSS, Chicago, IL, USA) and SAS version 9.1 (SAS Institute, Cary, NC, USA).

\section{RESULTS}

GGH overexpression system. HCT116 and MDA-MB-435 cells expressing the sense GGH had significantly higher steady-state levels of the GGH protein and GGH activity $(P<0.001)$ compared with corresponding controls expressing endogenous GGH (Figure 1A and C). Total intracellular folate concentration (i.e., folate levels after conjugase treatment) of HCT116 and MDAMB-435 cells expressing the sense GGH was significantly lower compared with corresponding controls $(P<0.01$; Figure $1 \mathrm{~B}$ and $\mathrm{D})$. Concentration of long-chain polyglutamates (i.e., differences between folate concentrations for conjugase-treated and -untreated samples) of HCT116 and MDA-MB-435 cells expressing the sense GGH was significantly lower compared with corresponding controls $(P<0.03$; Figure $1 \mathrm{~B}$ and $\mathrm{D})$. These observations confirm the appropriate functional consequences of GGH overexpression in both HCT116 and MDA-MB-435 cells.

GGH inhibition system. HCT116 and MDA-MB-435 cells transfected with the GGH-targeted siRNA had significantly lower steady-state levels of the GGH protein and GGH activity $(P<0.001)$ compared with corresponding controls expressing endogenous GGH (Figure 2A and $\mathrm{C}$ ). Total intracellular folate concentration of HCT116 and MDA-MB-435 cells transfected with the GGH-targeted siRNA was significantly higher compared with corresponding controls $(P<0.001$; Figure $2 \mathrm{~B}$ and $\mathrm{D})$. Intracellular long-chain folylpolyglutamate concentration of HCT116 and MDA-MB-435 cells transfected with the GGH-targeted siRNA was significantly higher compared with corresponding controls $(P<0.02$; Figure $2 \mathrm{~B}$ and $\mathrm{D})$. These observations confirm the appropriate functional consequences of GGH inhibition in both HCT116 and MDA-MB-435 cells.

Effects of GGH modulation on TS and DHFR. The catalytic activity of TS in HCT116 and MDA-MB-435 cells expressing the sense GGH was significantly lower compared with corresponding controls $(P<0.01$; Table 1$)$. The catalytic activity of TS in both cell lines transfected with the GGH-targeted siRNA was significantly higher compared with corresponding controls $(P<0.04$; Table 1$)$.

HCT116 and MDA-MB-435 cells expressing the sense GGH had significantly lower steady-state levels of the DHFR protein $(P<0.05$; data not shown $)$ and DHFR activity $(P<0.02$; Table 1$)$ compared with corresponding controls. In both cell lines, cells transfected with the GGH-targeted siRNA had significantly higher levels of the DHFR protein $(P<0.02$; data not shown) and DHFR activity $(P<0.03$; Table 1$)$ compared with corresponding controls. 


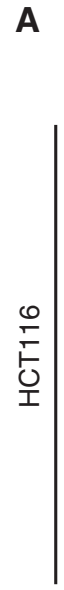

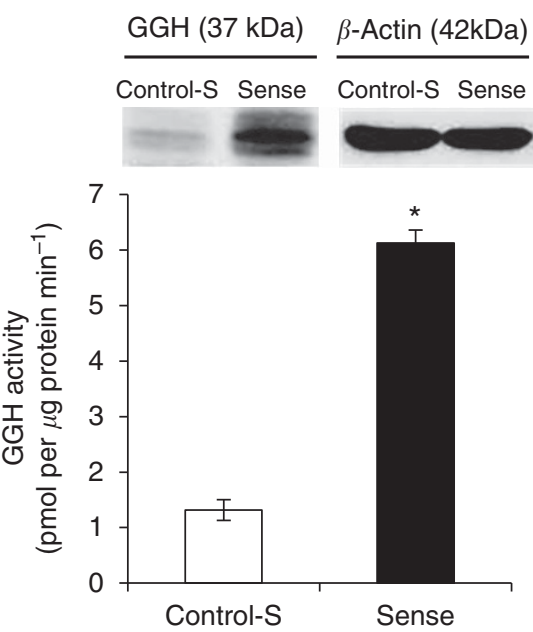

C

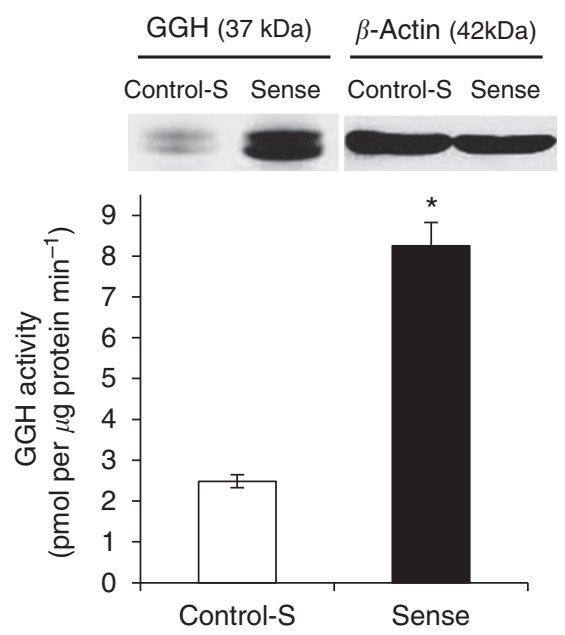

B

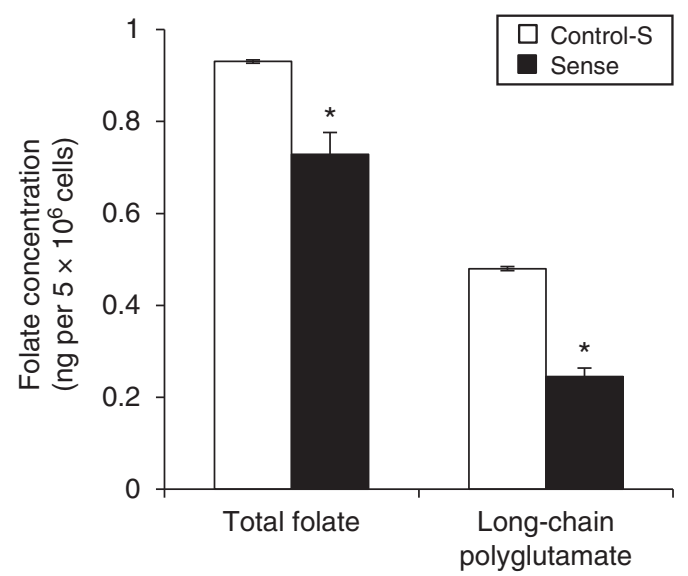

D

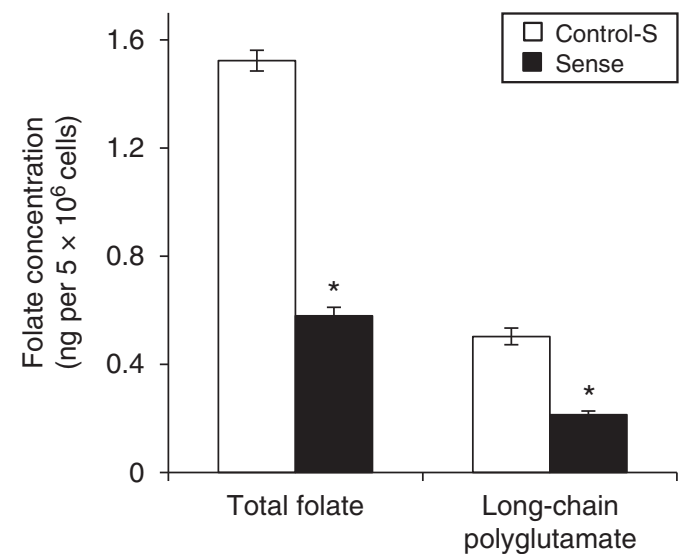

Figure 1. GGH overexpression system in HCT116 and MDA-MB-435 cells. HCT116 and MDA-MB-435 cells expressing the sense GGH (Sense) had significantly higher steady-state levels of the GGH protein and GGH activity (A and $\mathbf{C})$ compared with cells transfected with the vector alone (Control-S; endogenous $G G H ;{ }^{*} P<0.001$ ). In both cell lines, total intracellular folate concentrations (i.e., folate levels after conjugase treatment) were lower in the Sense compared with corresponding controls ( ${ }^{*} P<0.01 ; \mathbf{B}$ and $\mathbf{D}$ ). Concentrations of long-chain polyglutamates (i.e., differences between folate concentrations for conjugase-treated and -untreated samples) were significantly lower in the Sense in both cell lines compared with corresponding controls ( ${ }^{\star} P<0.03 ; \mathbf{B}$ and $\left.\mathbf{D}\right)$.

Effects of folate and GGH modulation on growth rate. In both cell lines, cells overexpressing GGH exhibited a significantly increased doubling time compared with corresponding controls at all three folate concentrations, indicating a slower growth rate $(P<0.001$; Supplementary Table $\mathrm{S} 1)$. This observation is consistent with the observed lower total intracellular folate and long-chain folylpolyglutamate concentrations and decreased TS activity associated with GGH overexpression.

Interestingly, the effect of GGH inhibition on growth rate was influenced by medium folate concentrations. As expected, based on the observed higher total intracellular folate and long-chain folylpolyglutamate concentrations and increased TS activity associated with GGH inhibition, HCT116 cells transfected with the GGH-targeted siRNA had a significantly decreased doubling time (i.e., a faster growth rate) compared with controls at 50 and $100 \mathrm{nmoll}^{-1}$ 5-MTHF $(P<0.001$; Supplementary Table S1). Unexpectedly, HCT116 cells transfected with the GGH-targeted siRNA had a significantly increased doubling time compared with controls at $2.3 \mu \mathrm{moll}^{-1}$ folic acid $(P<0.001$; Supplementary Table S1). Similarly, MDA-MB-435 cells in which GGH was inhibited showed a significantly decreased doubling time only at $50 \mathrm{nmoll}^{-1}$
5-MTHF but a significantly increased doubling time at $100 \mathrm{nmoll}^{-1} 5$-MTHF and $2.3 \mu \mathrm{moll}^{-1}$ folic acid compared with controls $(P<0.001$; Supplementary Table S1).

Effects of folate and GGH modulation on in vitro $5 \mathrm{FU}$ chemosensitivity. Our a priori hypothesis was that GGH overexpression would decrease the cytotoxic effect of $5 \mathrm{FU}$ by decreasing relative intracellular concentration of long-chain 5,10-methyleneTHF-polyglutamates, resulting in less efficient formation and stabilisation of the inhibitory 5,10-methyleneTHF-TS-FdUMP ternary complex. Consistent with our hypothesis, GGH overexpression significantly, albeit very modestly, decreased chemosensitivity of HCT116 cells to $5 \mathrm{FU}+\mathrm{LV}$ at $2.3 \mu \mathrm{mol} \mathrm{l}^{-1}$ folic acid $\left(P<0.05\right.$; Figure $3 \mathrm{C}$; $\mathrm{IC}_{50}$ values in Supplementary Table S2). Interestingly, this effect was not observed at $100 \mathrm{nmoll}^{-1} 5$-MTHF (Figure 3B) and at $50 \mathrm{nmoll}^{-1} 5$-MTHF GGH overexpression paradoxically increased chemosensitivity of HCT116 cells to $5 \mathrm{FU}+\mathrm{LV} \quad(P<0.05$; Figure 3A; Supplementary Table S2). In contrast, consistent with our hypothesis, GGH overexpression significantly decreased chemosensitivity of MDA-MB-435 cells to $5 \mathrm{FU}+\mathrm{LV}$ at 50 and $100 \mathrm{nmoll}^{-1} 5$-MTHF with a more 

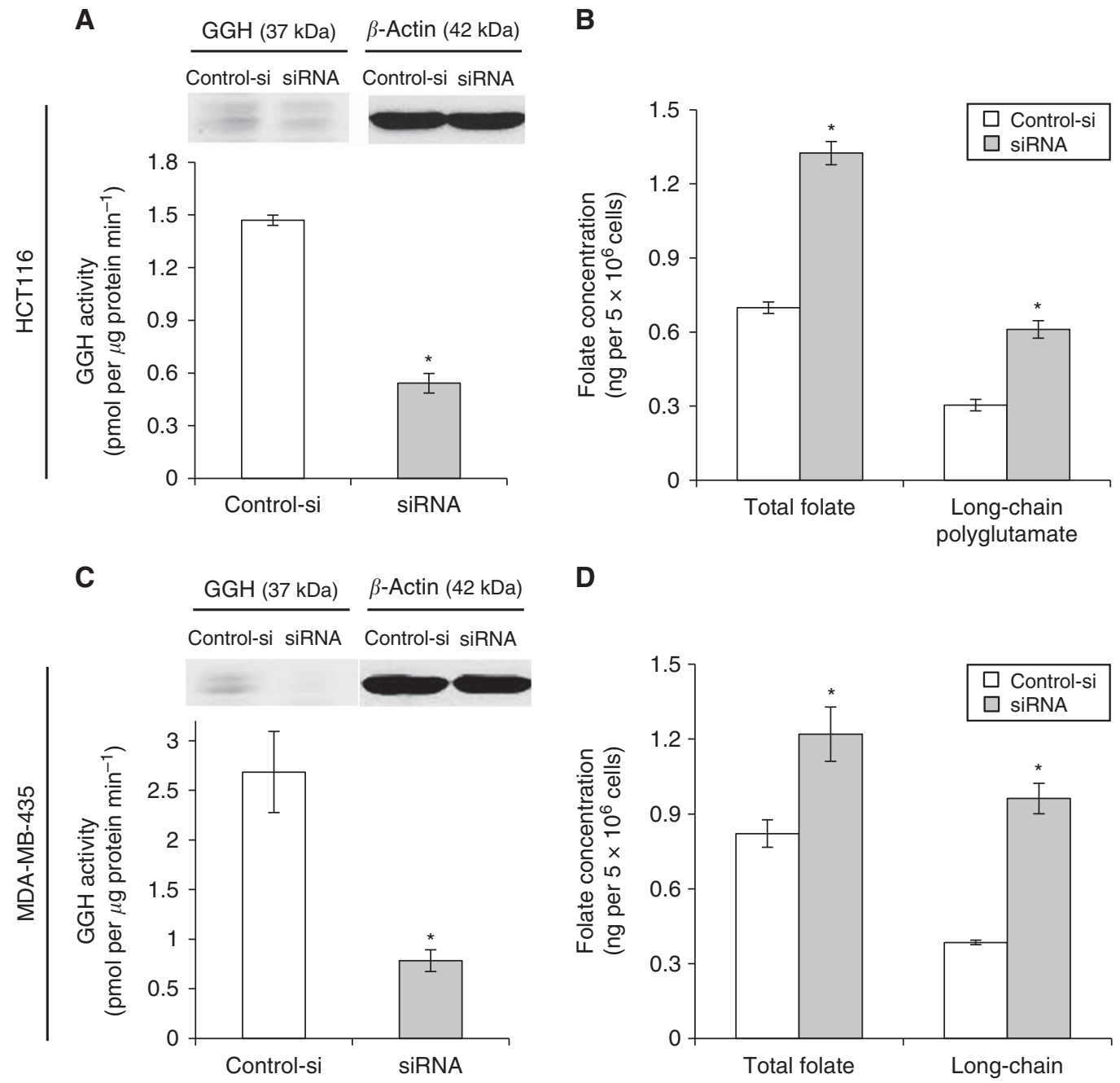

D

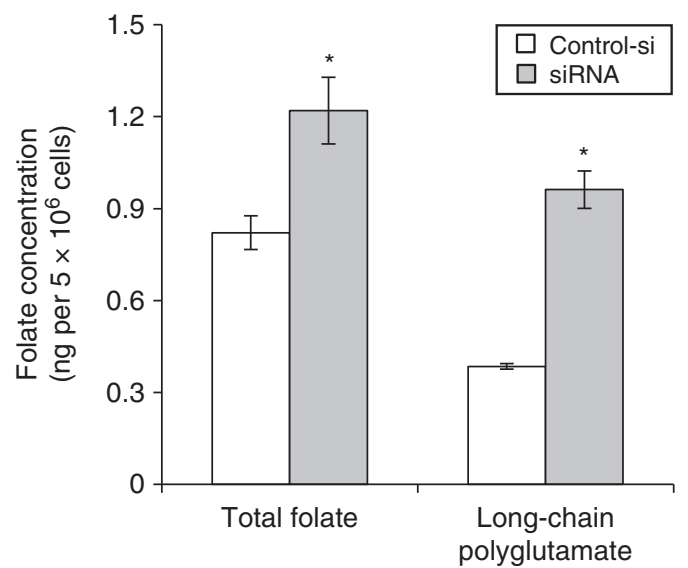

Figure 2. GGH inhibition system in HCT116 and MDA-MB-435 cells. HCT116 and MDA-MB-435 cells transfected with the GGH-targeted siRNA (siRNA) had significantly lower steady-state levels of the GGH protein and GGH activity (A and $\mathbf{C}$ ) compared with cells transfected with the vector alone (Control-si; endogenous GGH; ${ }^{*} P<0.001$ ). Total intracellular folate concentrations (i.e., folate levels after conjugase treatment) were significantly higher in the siRNA in both cell lines compared with corresponding controls $\left({ }^{\star} P<0.001\right.$; $\mathbf{B}$ and $\left.\mathbf{D}\right)$. Concentrations of long-chain polyglutamates (i.e., differences between folate concentrations for conjugase-treated and -untreated samples) were significantly higher in the siRNA in both cell lines compared with corresponding controls ( ${ }^{*} P<0.02 ; \mathbf{B}$ and $\left.\mathbf{D}\right)$.

Table 1. TS catalytic activity and DHFR activity in HCT116 and MDA-MB-435 cells transfected with the sense GGH and GGH-targeted siRNA in comparison with corresponding control cells expressing endogenous GGH

\begin{tabular}{|c|c|c|c|c|c|}
\hline & & \multicolumn{2}{|c|}{ GGH overexpression } & \multicolumn{2}{|c|}{ GGH inhibition } \\
\hline Cell line & Enzyme activity & Control-S & Sense & Control-si & siRNA \\
\hline \multirow[t]{2}{*}{ HCT116 } & TS catalytic activity ( $\mathrm{pmol} \mathrm{h}^{-1}$ per $\mathrm{mg}$ protein) & $2067.8 \pm 12.5$ & $1246.1 \pm 10.2^{\star}$ & $694.1 \pm 125.9$ & $1005.1 \pm 106.2^{*}$ \\
\hline & DHFR activity (a.u.) & $9.3 \pm 1.7$ & $3.9 \pm 0.4^{*}$ & $1.4 \pm 0.3$ & $4.4 \pm 0.3^{\star}$ \\
\hline \multirow[t]{2}{*}{ MDA-MB-435 } & TS catalytic activity (pmol $\mathrm{h}^{-1}$ per $\mathrm{mg}$ protein) & $845.7 \pm 55.2$ & $627.6 \pm 40.7^{*}$ & $742.7 \pm 33.4$ & $1032.5 \pm 74.4^{*}$ \\
\hline & DHFR activity (a.u.) & $3.3 \pm 0.2$ & $1.7 \pm 0.7^{*}$ & $0.9 \pm 0.2$ & $1.9 \pm 0.4^{*}$ \\
\hline
\end{tabular}

pronounced effect at $100 \mathrm{nmoll}^{-1} 5$-MTHF and at $2.3 \mu \mathrm{moll}{ }^{-1}$ folic acid, which demonstrated the most prominent effect $(P<0.05$; Figure 3D-F; Supplementary Table S3).

We hypothesised that GGH inhibition would increase the cytotoxic effect of $5 \mathrm{FU}$ by increasing relative intracellular concentrations of long-chain 5,10-methyleneTHF-polyglutamates, resulting in more efficient formation and stabilisation of the 5,10-methyleneTHF-TS-FdUMP ternary complex. Consistent with our hypothesis, GGH inhibition significantly increased chemosensitivity of HCT116 cells to $5 \mathrm{FU}+\mathrm{LV}$ at 50 and $100 \mathrm{nmoll}^{-1}$ 5-MTHF and $2.3 \mu \mathrm{moll}^{-1}$ folic acid $(P<0.05$; Figure 4A-C; Supplementary Table S2). Similarly, GGH inhibition 

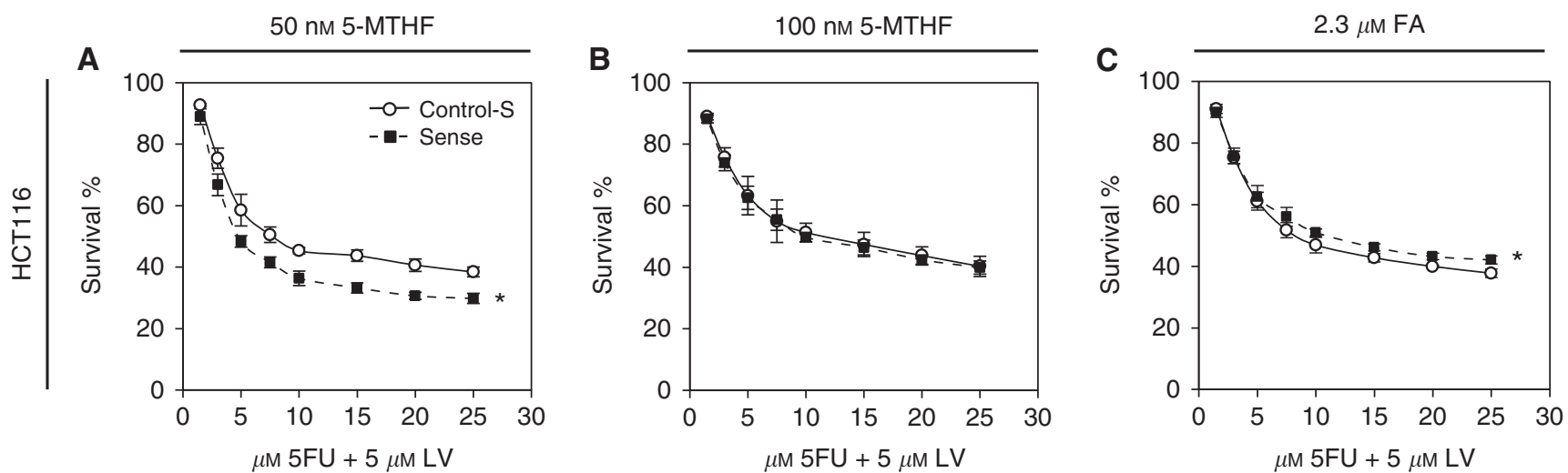

D

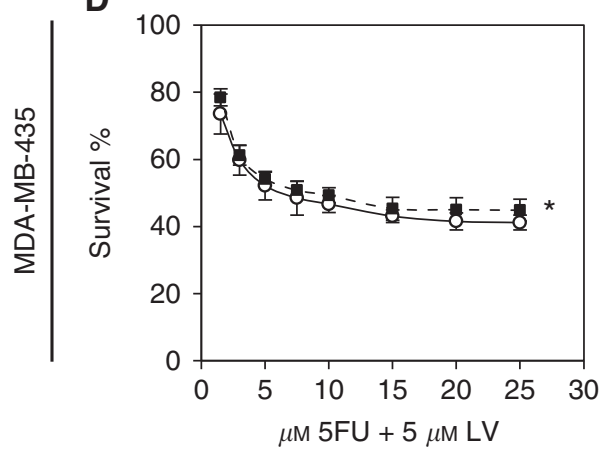

E

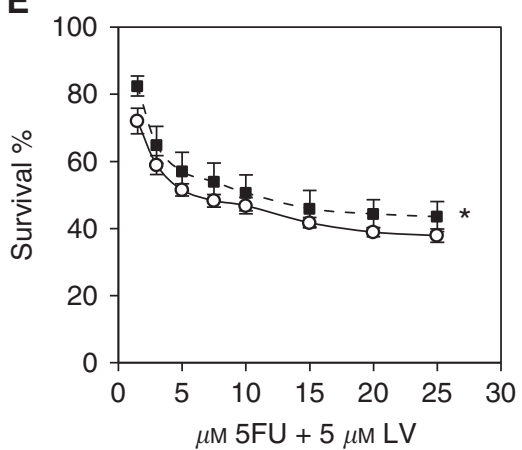

$\mathbf{F}$

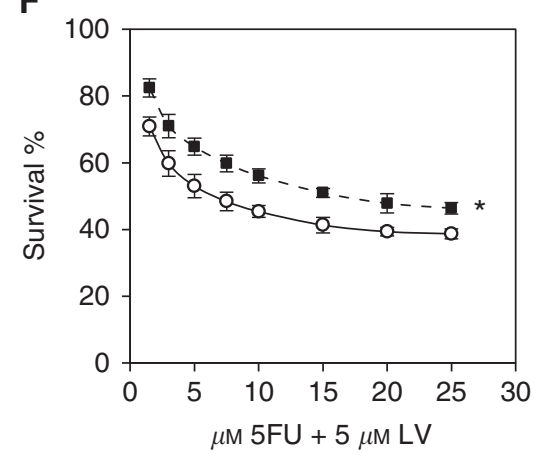

Figure 3. Effect of GGH overexpression on 5FU chemosensitivity. In vitro chemosensitivity of HCT116 colon and MDA-MB-435 breast cancer cells transfected with the sense GGH (Sense) to $5 F U$ + LV in comparison with cells transfected with the vector alone (Control-S; endogenous GGH) was determined using a modification of the sulphorhodamine protein assay. Cells were grown in medium containing $50 \mathrm{nmol} \mathrm{I}^{-1} 5-\mathrm{MTHF}$ (A and D), $100 \mathrm{nmoll}^{-1}$ 5-MTHF (B and E) or $2.3 \mu \mathrm{moll}{ }^{-1}$ folic acid (FA; C and F). Points, means; bars, s.d.; ${ }^{\star} P<0.05$, statistically significant compared with corresponding control cells.

significantly increased chemosensitivity of MDA-MB-435 cells to $5 \mathrm{FU}+\mathrm{LV}$ at $100 \mathrm{nmoll}^{-1} 5$-MTHF and $2.3 \mu \mathrm{moll}^{-1}$ folic acid $(P<0.05)$, but not at $50 \mathrm{nmoll}^{-1} 5$-MTHF (Figure 4D-F; Supplementary Table S3). In both cell lines, the degree of the enhanced chemosensitivity to $5 \mathrm{FU}+\mathrm{LV}$ was higher at $100 \mathrm{nmoll}^{-1} 5$-MTHF than at $50 \mathrm{nmoll}^{-1}$ 5-MTHF, and was most pronounced at $2.3 \mu \mathrm{moll}^{-1}$ folic acid (Figure 4A-F; Supplementary Tables S2 and S3).

Effects of folate and GGH overexpression on in vivo 5FU chemosensitivity. We next confirmed the in vitro chemosensitivity of HCT116 cells overexpressing GGH to 5FU + LV in nude mice and determined whether dietary folic acid supplementation would further influence the effect of GGH overexpression on chemosensitivity. We chose the HCT116 GGH overexpression system for the in vivo study for two reasons: (1) the magnitude of cell survival difference was more pronounced in this system compared with other systems and (2) the in vitro chemosensitivity to $5 \mathrm{FU}$ demonstrated an interesting modifying effect of exogenous folate. The mean plasma folate concentrations of the folic acidsupplemented mice $\left(129.2 \pm 7.7 \mathrm{nmoll}^{-1}\right.$ in $5 \mathrm{FU}+\mathrm{LV}$-treated mice; $118.0 \pm 12.7 \mathrm{nmoll}^{-1}$ in $0.9 \%$ saline-treated mice) were significantly higher than those of mice on the control diet $(84.5 \pm 9.3$ in $5 \mathrm{FU}+\mathrm{LV}$-treated mice; $82.9 \pm 4.5$ in saline-treated mice) $(P<0.001)$. Treatment with $5 \mathrm{FU}+\mathrm{LV}$ had no effect on plasma folate concentrations.

For each diet, the difference in the growth rates of xenografts between cell types (GGH overexpression versus control endogenous GGH) depended on treatment, and the effect of treatment depended on the cell types ( $\mathrm{P}$-interaction for treatment $\times$ cell types $=0.037$ for $2 \mathrm{mg}$ folic acid diet and $<0.0001$ for $8 \mathrm{mg}$ folic acid diet). When the growth rates of the xenografts in mice injected with saline were compared, the GGH-overexpressing xenografts grew slower than the xenografts expressing endogenous GGH at both dietary folic acid levels (at $2 \mathrm{mg}$ folic acid per $\mathrm{kg}$ diet: $\mathrm{RTV}=0.78 \quad(95 \% \quad \mathrm{CI}=0.65-0.94), \quad P=0.011 ; \quad$ at $8 \mathrm{mg}$ folic acid per $\mathrm{kg}$ diet: $\mathrm{RTV}=0.55(95 \% \mathrm{CI}=0.52-0.58), P<0.0001)$; Figure $5 \mathrm{~A}$ and $\mathrm{B}$ ). These data are consistent with the observed increased doubling time and thus slower growth rates associated with GGH overexpression in HCT116 cells grown at all three folate concentrations (Supplementary Table S1).

The growth of the GGH-overexpressing xenografts was inhibited more effectively by $5 \mathrm{FU}+\mathrm{LV}$ than was the growth of those expressing endogenous GGH at the $2 \mathrm{mg}$ folic acid level (38\% inhibition (95\% CI $=32-43 \%), P<0.0001$; Figure 5C). This observation is consistent with the significantly increased in vitro chemosensitivity of the GGH-overexpressing HCT116 cells at $50 \mathrm{nmoll}^{-1}$ 5-MTHF (Figure 3A and Supplementary Table S2). In contrast, at the $8 \mathrm{mg}$ supplemental folic acid level, the growth of the xenografts expressing endogenous GGH was inhibited more effectively by $5 \mathrm{FU}+\mathrm{LV}$ than was the growth of those overexpressing GGH (36\% inhibition (95\% CI $=21-48 \%), P<0.0001$; Figure 5D). This observation is in agreement with the significantly decreased in vitro chemosensitivity of the GGH-overexpressing HCT116 cells at $2.3 \mu \mathrm{moll}^{-1}$ folic acid (Figure 3C and Supplementary Table S1).

Effects of folate and GGH modulation on in vitro MTX chemosensitivity. We predicted that the GGH overexpressioninduced decreased MTX polyglutamylation would decrease the cytotoxic effect of MTX. Consistent with our hypothesis, GGH overexpression significantly decreased chemosensitivity of HCT116 cells to MTX at $2.3 \mu \mathrm{moll}^{-1}$ folic acid $(P<0.05$; Figure 6C and Supplementary Table S2). Interestingly, this effect 

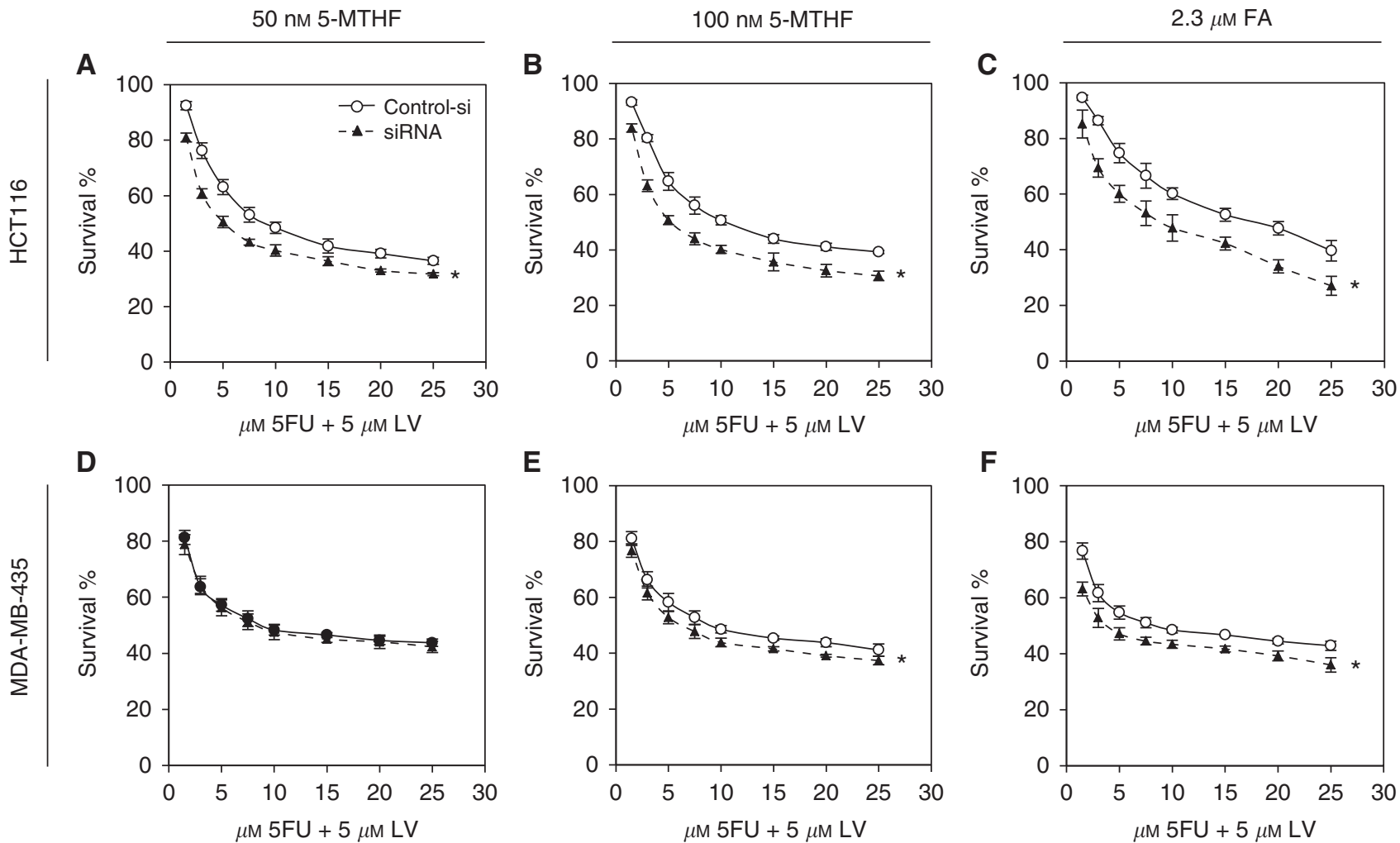

Figure 4. Effect of GGH inhibition on 5FU chemosensitivity. In vitro chemosensitivity of HCT116 colon and MDA-MB-435 breast cancer cells transfected with the GGH-targeted siRNA (siRNA) to 5FU + LV in comparison with cells transfected with the vector alone (Control-si; endogenous $\mathrm{GGH}$ ) was determined using a modification of the sulphorhodamine protein assay. Cells were grown in medium containing $50 \mathrm{nmol} \mathrm{I}^{-1} 5-\mathrm{MTHF}$ (A and D), $100 \mathrm{nmolI}^{-1}$ 5-MTHF (B and E), or $2.3 \mu \mathrm{mol} \mathrm{I}^{-1}$ folic acid (FA; $\mathbf{C}$ and F). Points, means; bars, s.d.; ${ }^{\star} P<0.05$, statistically significant compared with corresponding control cells.

was not observed at $100 \mathrm{nmoll}^{-1} 5$-MTHF (Figure 6B), and at $50 \mathrm{nmoll}^{-1}$ 5-MTHF GGH overexpression paradoxically increased chemosensitivity of HCT116 cells to MTX $(P<0.05$; Figure 6A and Supplementary Table S2). Consistent with our hypothesis, GGH overexpression significantly decreased chemosensitivity of MDA-MB-435 cells to MTX at 50 and $100 \mathrm{nmoll}^{-1}$ 5 -MTHF with a more pronounced effect at $100 \mathrm{nmoll}^{-1} 5$-MTHF and at $2.3 \mu \mathrm{moll}^{-1}$ folic acid, which demonstrated the most prominent effect $(P<0.05$; Figure $6 \mathrm{D}-\mathrm{F}$ and; Supplementary Table S3).

We hypothesised that the GGH inhibition-induced increased MTX polyglutamylation would enhance the cytotoxic effect of MTX. Interestingly, in contrast to our hypothesis, GGH inhibition paradoxically decreased chemosensitivity of both cell lines to MTX at 50 and $100 \mathrm{nmoll}^{-1} 5$-MTHF and $2.3 \mu \mathrm{moll}^{-1}$ folic acid $(P<0.05$; Figure 7A-F; Supplementary Tables S2 and S3). In both cell lines, the degree of the decreased chemosensitivity to MTX was greater at $100 \mathrm{nmoll}^{-1} 5$-MTHF than at $50 \mathrm{nmoll}^{-1} 5$-MTHF, and was most pronounced at $2.3 \mu \mathrm{moll}^{-1}$ folic acid (Figure $7 \mathrm{~A}-\mathrm{F}$; Supplementary Tables S2 and S3).

\section{DISCUSSION}

We developed an appropriate in vitro model of GGH overexpression and inhibition in HCT116 colon and MDA-MB-435 breast cancer cells with predictable functional consequences (summarised in Figure 8). Compared with controls expressing endogenous GGH, cells overexpressing GGH had significantly higher GGH protein expression and activity, lower total intracellular folate concentrations and lower content of long-chain folylpolyglutamates (Figure 8A). In contrast, cells transfected with the GGH-targeted siRNA had significantly lower GGH protein expression and activity, higher concentrations of total intracellular folate and higher content of long-chain folylpolyglutamates compared with controls expressing endogenous GGH (Figure 8B). Cells overexpressing GGH had a significantly slower growth rate compared with controls at all three folate concentrations. This is consistent with the observed decreased total intracellular folate concentrations and lower content of long-chain folylpolyglutamates, which are better substrates than short-chain folylpolyglutamates for folate-dependent enzymes involved in thymidylate and purine biosynthesis. Consistent with the growth data, cells overexpressing GGH had significantly lower TS activity and DHFR protein expression and activity. Consistent with the observed increased total intracellular folate concentrations, higher content of long-chain folylpolyglutamates, and higher TS activity and DHFR protein expression and activity, HCT116 in which GGH was inhibited exhibited a significantly faster growth rate compared with controls at 50 and $100 \mathrm{nmoll}^{-1}$ 5-MTHF. Similarly, the GGH-inhibited MDA-MB-435 cells showed a faster growth rate compared with controls at $50 \mathrm{nmoll}^{-1} 5$-MTHF. Unexpectedly, HCT116 and MDA-MB-435 cells transfected with the GGH-targeted siRNA had a slower growth rate compared with controls at $2.3 \mu \mathrm{moll}^{-1}$ folic acid, and at $100 \mathrm{nmoll}^{-1} 5$-MTHF and $2.3 \mu \mathrm{mol} 1^{-1}$ folic acid, respectively, which is not readily explained by the observed biochemical consequences of GGH inhibition. In general, most of the observed functional consequences of GGH overexpression and inhibition are consistent with the known biological function of GGH and provided an appropriate in vitro model to test the effect of GGH modulation on chemosensitivity of colon and breast cancer cells to $5 \mathrm{FU}$ and MTX (Figure 8). 

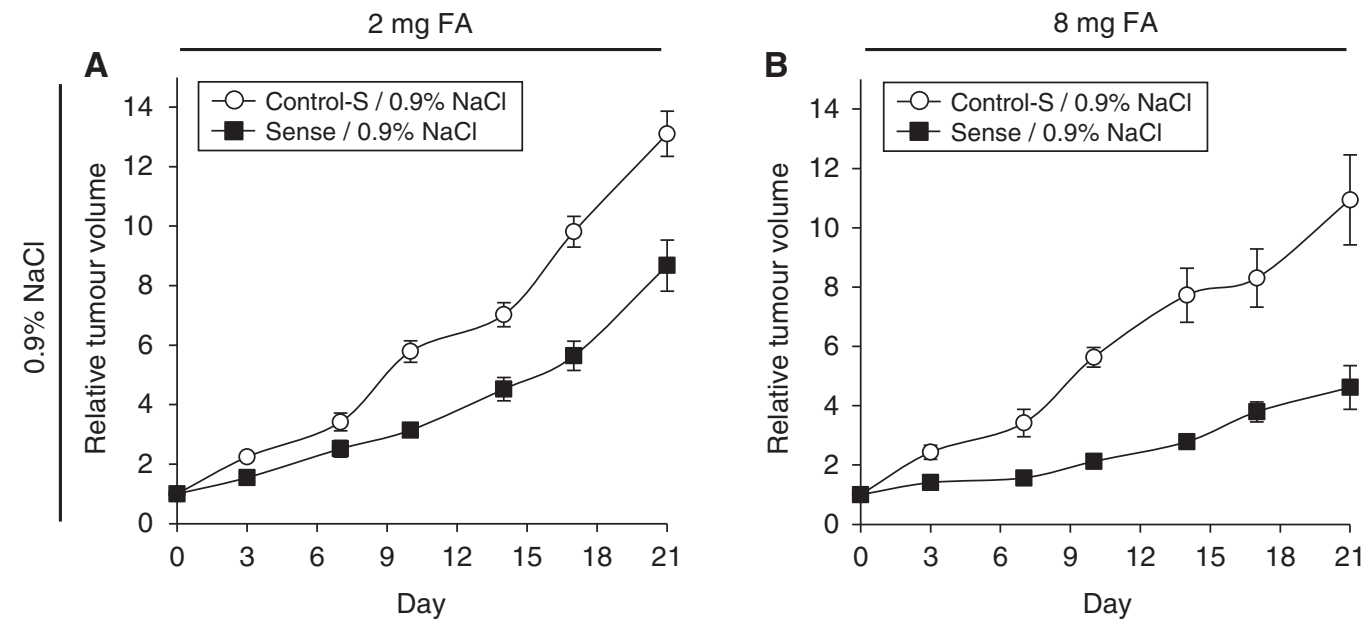

C
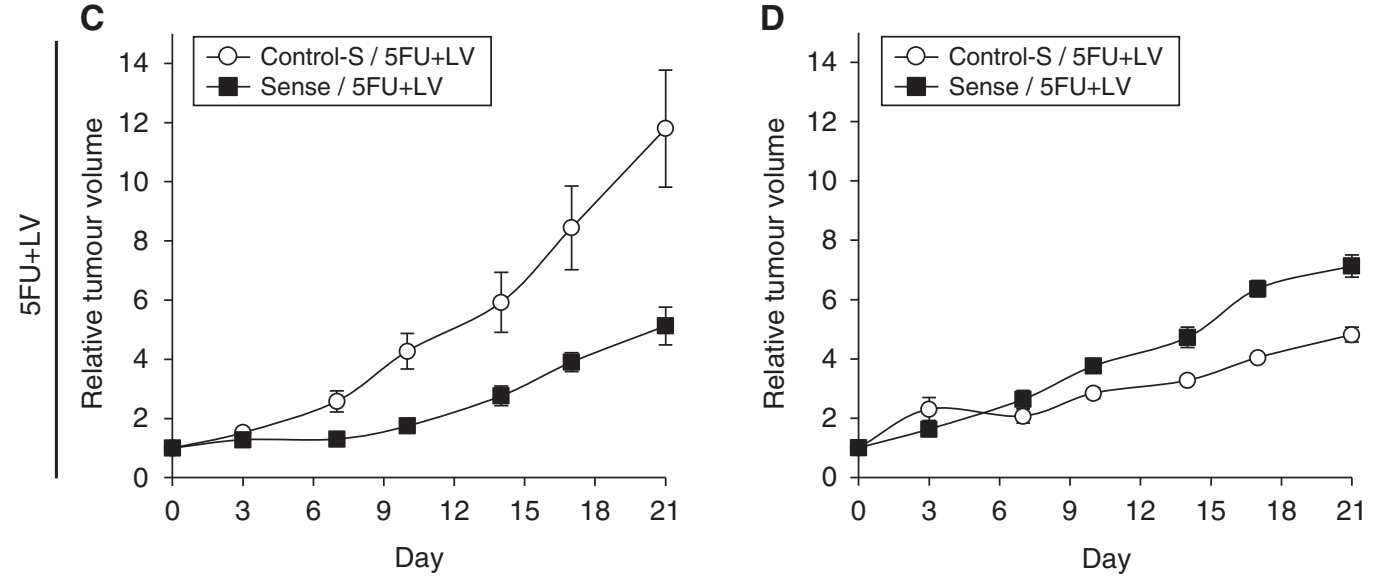

Figure 5. Effect of GGH overexpression and folic acid (FA) supplementation on 5FU chemosensitivity in nude mice. Twenty 6-week-old male $\mathrm{BALB} / \mathrm{c}$ nu/nu mice received subcutaneous injections in each flanks of HCT116 colon cancer cells expressing endogenous GGH (Control-S) and the sense GGH (Sense). When xenografts reached a volume of $80-200 \mathrm{~mm}^{3}$, mice were randomly assigned to receive either the control (2 mg FA per kg diet) or FA-supplemented ( $8 \mathrm{mg}$ FA per $\mathrm{kg}$ diet) diet ( $n=10$ per dietary group). Within each dietary group, mice received either $5 \mathrm{FU}+\mathrm{LV}$ or $0.9 \% \mathrm{NaCl}$ intraperitoneally ( $n=5$ per treatment group). Therefore, there were four groups of mice ( $n=5$ per group): (i) treated with $0.9 \% \mathrm{NaCl}$ and on the control diet; (ii) treated with $5 \mathrm{FU}+\mathrm{LV}$ and on the control diet; (iii) treated with $0.9 \% \mathrm{NaCl}$ and on the FA-supplemented diet; and (iv) treated with 5FU + LV and on the FA-supplemented diet. The estimated tumour volume (V) was calculated based on the formula $W^{2} \times L \times 0.5$, where $W$ represents the largest tumour diameter in centimetres and $L$ represents the next largest tumour diameter. The individual RTV was calculated as $V_{x} / V_{1}$, where $V_{x}$ is the volume in cubic millimetres at a given time and $V_{1}$ is the volume at the start of treatment. Results are expressed as the mean daily per cent change in tumour volume for each group of mice. When the growth rates of the xenografts in mice injected with saline were compared, the GGH-overexpressing xenografts grew slower than the xenografts expressing endogenous GGH at both dietary FA levels: (A) at $2 \mathrm{mg}$ FA per $\mathrm{kg}$ diet: $\mathrm{RTV}=0.78(95 \% \mathrm{Cl}=0.65-0.94), P=0.011$; (B) at $8 \mathrm{mg}$ FA per $\mathrm{kg} \operatorname{diet}: \mathrm{RTV}=0.55(95 \% \mathrm{Cl}=0.52-0.58)$, $P<0.0001)$. The growth of the GGH-overexpressing xenografts was inhibited more effectively by $5 F U+L V$ than was the growth of those expressing endogenous GGH at the $2 \mathrm{mg} \mathrm{FA}$ level (38\% inhibition $(95 \% \mathrm{Cl}=32-43 \%), \mathrm{P}<0.0001$; C). In contrast, at the 8 -mg supplemental FA level, the growth of the xenografts expressing endogenous GGH was inhibited more effectively by $5 \mathrm{FU}+\mathrm{LV}$ than was the growth of those overexpressing GGH (36\% inhibition (95\% $\mathrm{Cl}=21-48 \%), P<0.0001 ; \mathrm{D})$.

Our a priori hypothesis concerning the effects of GGH modulation on $5 \mathrm{FU}$ chemosensitivity was based on the assumption that the GGH modulation-induced change in intracellular concentration of long-chain 5,10-methyleneTHF-polyglutamates, which in turn affects the formation and stabilisation of the inhibitory 5,10-methyleneTHF-TS-FdUMP ternary complex, might be the primary determinant of 5FU chemosensitivity. This was indeed the case for the GGH overexpression system in MDAMB-435 cells and for the GGH inhibition system in both HCT116 and MDA-MB-435 cells (Figure 8). In these instances, folate appears to further influence the GGH modulation-induced 5FU chemosensitivity as suggested by the observation that the magnitude of change in 5FU chemosensitivity was greater in $100 \mathrm{nmoll}^{-1} 5$-MTHF than in $50 \mathrm{nmoll}^{-1} 5$-MTHF, which represent a nutritionally relevant physiological range of high and normal serum/plasma folate concentrations, respectively (Figure 8). In these instances, the magnitude of change in 5FU chemosensitivity was most pronounced at $2.3 \mu \mathrm{moll}^{-1}$ folic acid, which represents an extremely high supraphysiological level of an unnatural form of folate (Figure 8). For the GGH overexpression system in HCT116 cells, however, the predicted decreased 5FU chemosensitivity was observed only at $2.3 \mu \mathrm{moll}^{-1}$ folic acid, whereas this effect was not observed at 100 and at $50 \mathrm{nmoll}^{-1}$ 5-MTHF, GGH overexpression was associated with paradoxically, albeit very modestly, increased 5FU chemosensitivity (Figure 8A). It appears that at $50 \mathrm{nmoll}^{-1} 5$-MTHF, GGH overexpression decreased total intracellular folate concentrations and contents of long-chain polyglutamates of other intracellular folate cofactors to 

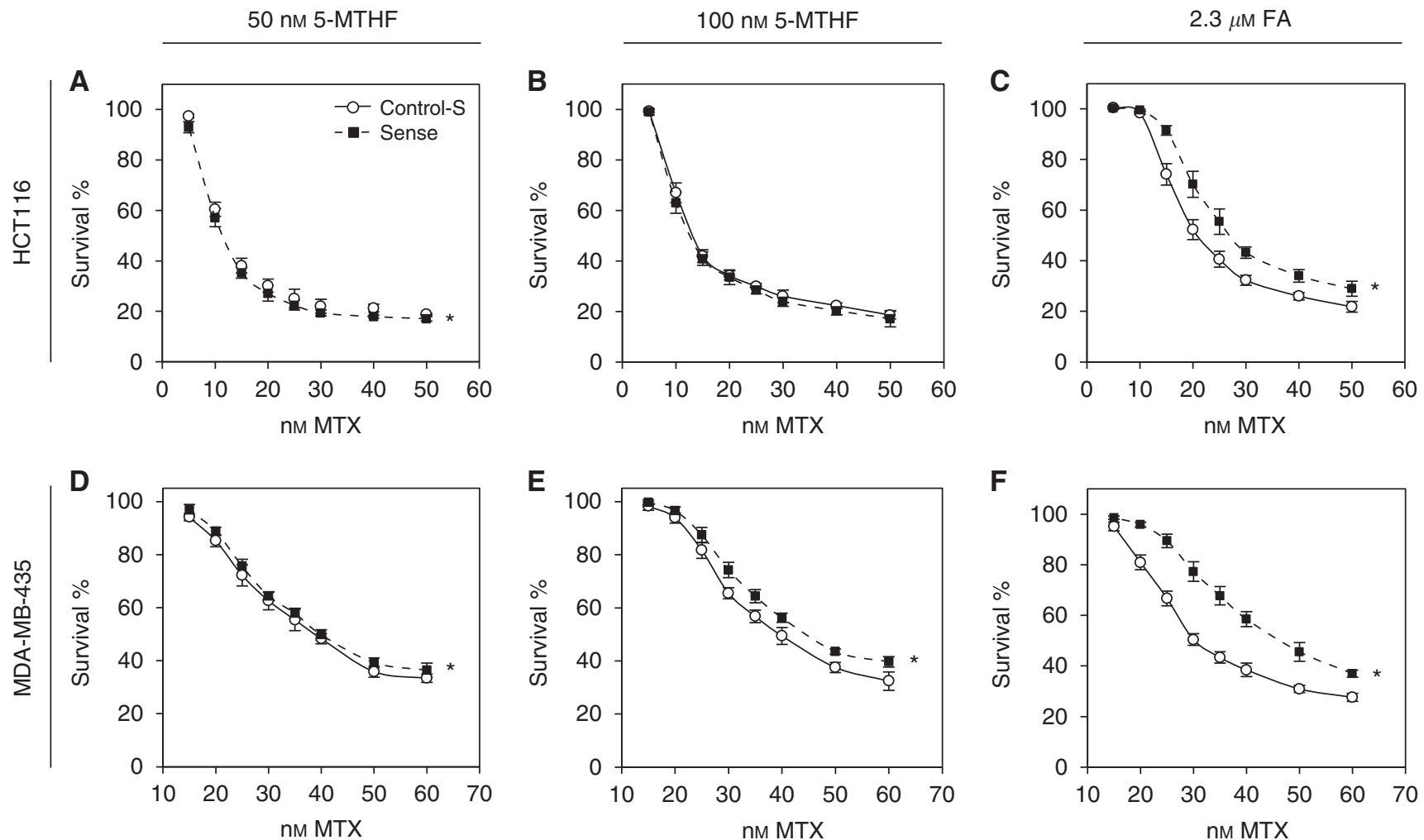

Figure 6. Effect of GGH overexpression on MTX chemosensitivity. In vitro chemosensitivity of HCT116 colon and MDA-MB-435 breast cancer cells transfected with the sense GGH (Sense) to MTX in comparison with cells transfected with the vector alone (Control-S; endogenous $\mathrm{GGH}$ ) was determined using a modification of the sulphorhodamine protein assay. Cells were grown in medium containing $50 \mathrm{nmol} \mathrm{I}^{-1} 5-\mathrm{MTHF}$ (A and D), $100 \mathrm{nmolI}^{-1}$ 5-MTHF (B and E), or $2.3 \mu \mathrm{moll}{ }^{-1}$ folic acid (FA; C and F). Points, means; bars, s.d.; ${ }^{\star} P<0.05$, statistically significant compared with corresponding control cells.

a greater extent than long-chain 5,10-methyleneTHF-polyglutamates in HCT116 cells, resulting in decreased thymidylate and purine biosynthesis. This might have overridden the effect of decreased long-chain 5,10-methyleneTHF-polyglutamates, resulting in increased 5FU cytotoxicity. At $100 \mathrm{nmoll}^{-1} 5$-MTHF, the competing effects of decreased DNA synthesis associated with decreased intracellular total folate concentrations and contents of long-chain folylpolyglutamates and of less TS inhibiting effect associated with decreased long-chain 5,10-methyleneTHF-polyglutamates seem to have cancelled each other out. We confirmed the effect of GGH overexpression on in vitro 5FU chemosensitivity of HCT116 cells and the modulating effect of exogenous folate levels on the GGH overexpression effect on 5FU chemosensitivity in vivo.

Our a priori hypothesis concerning the effects of GGH modulation on MTX chemosensitivity was based on the assumption that the GGH modulation-induced change in MTX polyglutamylation might be the primary determinant of MTX chemosensitivity. This was indeed the case for the GGH overexpression system in MDA-MB-435 cells (Figure 8A). In this instance, folate appears to further influence the GGH modulationinduced MTX chemosensitivity as suggested by the observation that the magnitude of change in MTX chemosensitivity was greater in $100 \mathrm{nmoll}^{-1} 5$-MTHF than in $50 \mathrm{nmoll}^{-1} 5$-MTHF, and was most pronounced at $2.3 \mu \mathrm{moll}^{-1}$ folic acid (Figure $8 \mathrm{~A}$ ). For the GGH overexpression system in HCT116 cells, however, the predicted decreased MTX chemosensitivity was observed only at $2.3 \mu \mathrm{moll}^{-1}$ folic acid, whereas this effect was not observed at $100 \mathrm{nmoll}^{-1}$ and at $50 \mathrm{nmoll}^{-1} 5$-MTHF GGH expression was associated with paradoxically, albeit very modestly, increased MTX chemosensitivity (Figure 8A). This suggests that decreased intracellular concentrations of total folate and long-chain folylpolyglutamates, which would decrease DNA synthesis, associated with GGH overexpression overwhelmed the effect of decreased MTX polyglutamylation, resulting in enhanced MTX chemosensitivity at $50 \mathrm{nmoll}^{-1}$ in HCT116 cells. However, at $100 \mathrm{nmoll}^{-1}$, the magnitude of intracellular depletion of total and long-chain folylpolyglutamates associated with GGH overexpression cancelled out the counterbalancing effect of the GGH overexpressioninduced decreased MTX polyglutamylation.

In contrast to our a priori hypothesis that the GGH inhibitioninduced increased MTX polyglutamylation would enhance the cytotoxic effect of MTX, GGH inhibition significantly decreased MTX chemosensitivity at all three folate concentrations in both cell lines (Figure 8B). This suggests that increased intracellular concentrations of total folate and long-chain folylpolyglutamates, which would provide an increased amount of substrates for nucleotide biosynthesis, and increased TS and DHFR activity associated with GGH inhibition were the primary determinants of the observed decreased chemosensitivity of colon and breast cancer cells to MTX at all three folate concentrations rather than the GGH inhibition-induced increased MTX polyglutamylation, which should have enhanced MTX chemosensitivity. Nevertheless, the modulating effect of folate on the GGH inhibition-induced MTX cytotoxicity was still evident in both cell lines as the magnitude of change in MTX chemosensitivity was greater in $100 \mathrm{nmoll}^{-1}$ 5 -MTHF than in $50 \mathrm{nmoll}^{-1} 5$-MTHF, and was most pronounced at $2.3 \mu \mathrm{moll}^{-1}$ folic acid (Figure 8B).

Clinical studies investigating the role of GGH in modulating chemosensitivity to 5FU and antifolates have begun to emerge. Low GGH expression was reported to correlate with an enhanced response to 5FU-based chemotherapy in patients with metastatic 

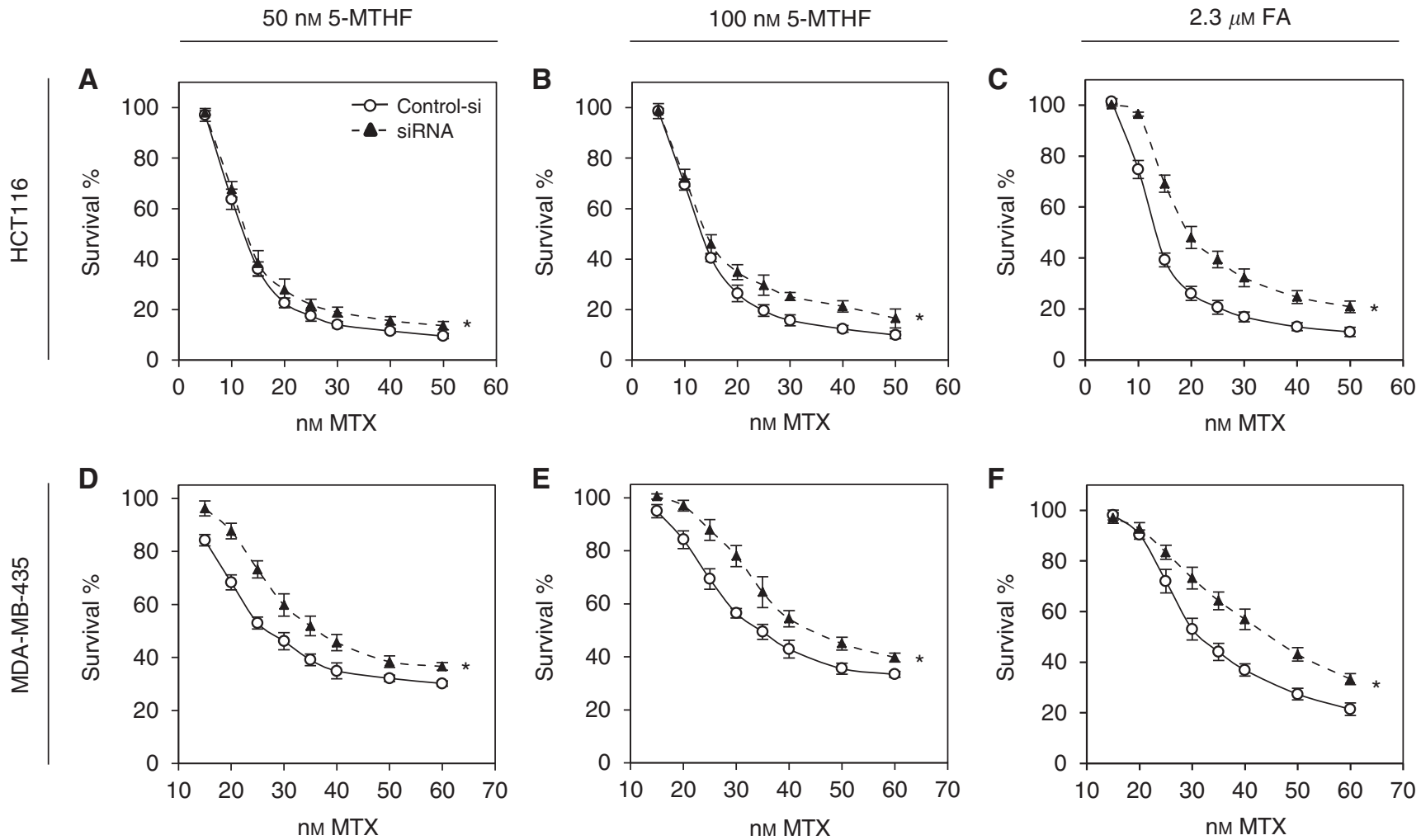

Figure 7. Effect of GGH inhibition on MTX chemosensitivity. In vitro chemosensitivity of HCT116 colon and MDA-MB-435 breast cancer cells transfected with the GGH-targeted siRNA (siRNA) to MTX in comparison with cells transfected with the vector alone (Control-si; endogenous GGH) was determined using a modification of the sulphorhodamine protein assay. Cells were grown in medium containing $50 \mathrm{nmol} \mathrm{I}^{-1} 5-\mathrm{MTHF}$ (A and D), 100 nmol I $^{-1}$ 5-MTHF (B and E), or $2.3 \mu$ moll ${ }^{-1}$ folic acid (FA; C and F). Points, means; bars, s.d.; ${ }^{\star} P<0.05$, statistically significant compared with corresponding control cells.
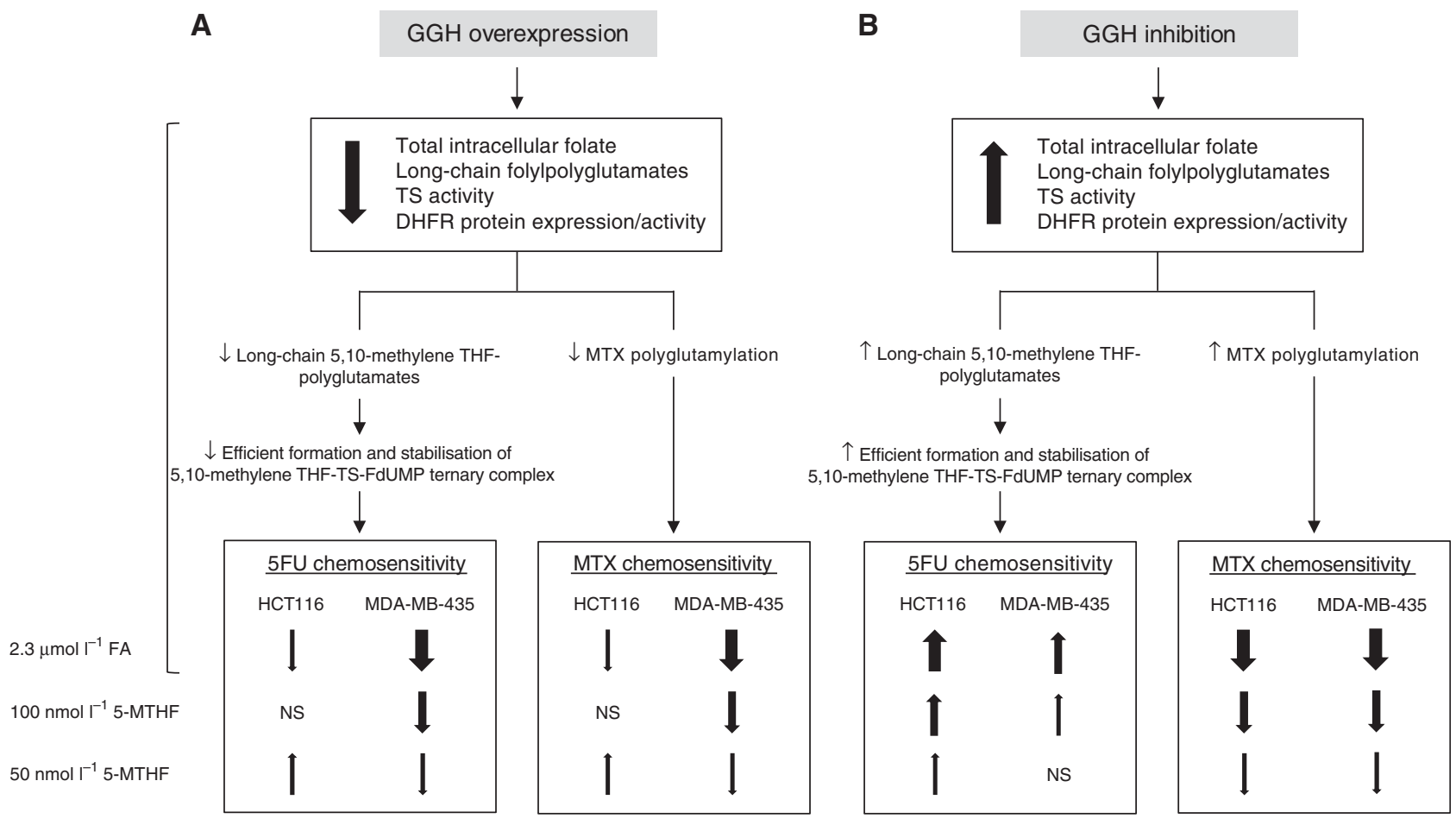

Figure 8. Summary of the effects of GGH modulation and folate. Summary of the functional consequences of GGH overexpression (A) and inhibition (B) and the effects of GGH overexpression (A) and inhibition (B) and folate on 5FU and MTX chemosensitivity in HCT116 colon and MDAMB-435 breast cancer cells. 
colorectal cancer (Nakajima et al, 2008). In patients with advanced pancreatic cancer treated with an oral fluoropyrimidine derivative, S-1, low GGH expression was associated with improved overall survival (Nakamura et al, 2011). In acute myelogenous leukemia, it was found that high GGH activity may have a role in inherent drug resistance to MTX (Rots et al, 1999). High GGH expression was shown to be associated with a higher risk of developing advanced toxicity to pemetrexed, a multi-targeted antifolate, in patients with advanced breast cancer (Llombart-Cussac et al, 2007). A recent study has reported that high GGH protein level is associated with poor prognosis and unfavourable clinical outcomes in patients with invasive breast cancer (Shubbar et al, 2013). Furthermore, several recently identified and characterized functionally significant genetic and epigenetic polymorphisms of GGH have been reported to predict response to and toxicity of antifolate-based treatment in patients with several cancers (Cheng et al, 2004; Kim et al, 2008; Koomdee et al, 2012; Smit et al, 2012; Silva et al, 2013) and inflammatory arthritis (Dervieux et al, 2004; van der Straaten et al, 2007; Hayashi et al, 2009; Yanagimachi et al, 2011; Owen et al, 2012; Jekic et al, 2013).

Intracellular folate and antifolate accumulation and metabolism, including polyglutamylation, are affected by multiple enzymes in the highly complex folate metabolic pathway (Schneider and Ryan, 2006). Furthermore, changes in a single enzyme such as GGH induce a cascade of adaptive and compensatory changes in other enzymes in order to maintain folate and antifolate homeostasis (Shane, 2010). Thus, the attribution of changes in chemosensitivity of cancer cells to 5FU and antifolates to a single enzyme such as GGH is difficult. Most likely, GGH modulation is but one of several factors that affect cancer cells' sensitivity to $5 \mathrm{FU}$ and antifolates. In addition to changes in polyglutamylation of 5,10methyleneTHF and antifolates, GGH modulation might have also induced changes in drug uptake into and accumulation in the cells, the forward polyglutamylation reaction by FPGS, intracellular concentration and polyglutamylation of other folate cofactors, intracellular distribution of the various folate species between cytoplasm, lysosome and mitochondria, and/or transport mechanisms of folates and antifolates into the lysosomes where GGH resides and out of the cells by various ATP-binding cassette transporters (Schneider and Ryan, 2006). These adaptive and compensatory changes have likely had a role in modifying the effects of GGH modulation on chemosensitivity of cancer cells to $5 \mathrm{FU}$ and antifolates. Some of the differences between the two cell lines are likely caused by differences in this complexity. Furthermore, HCT116 and MDA-MB-435 cell lines may differ in common polymorphisms in several genes in the folate metabolic pathway and one-carbon transfer reactions such as methylenetetrahydrofolate reductase (MTHFR), TS, DHFR, methionine synthase, methionine synthase reductase, serine hydroxymethyltransferase and reduced folate carrier. This might have contributed to the observed differences between the two cell lines. In this regard, endogenous TS and DHFR activity were significantly different between the two cell lines as shown in Table 1, whereas both cell lines are heterozygous for the MTHFR C677T genotype (Sohn et al, 2004a).

In conclusion, as a proof-of-principle we provide evidence that GGH modulation affects chemosensitivity of colon and breast cancer cells to 5FU and MTX. Our data suggest that the effects of GGH modulation on chemosensitivity of colon and breast cancer cells to 5FU and MTX cannot be predicted solely based on the GGH modulation-induced changes in polyglutamylation of 5,10methyleneTHF and MTX, respectively, as we have demonstrated that exogenous folate forms and levels can further influence the effects of GGH modulation on 5FU and MTX chemosensitivity. High GGH status may predict resistance to 5FU- and MTX-based chemotherapy in breast cancer treatment, but for colon cancer this may largely depend on dietary intake and blood levels of folate.
At normal intake or blood-level folate high GGH status may enhance the response of colon cancer cells to 5FU-based chemotherapy, whereas at high intake or blood levels this enhanced chemosensitivity to 5FU may be abolished and high GGH status may even decrease 5FU chemosensitivity. On the other hand, GGH inhibition may be a potential target for increasing chemosensitivity of colon and breast cancer cells to 5FU but not to MTX. Notwithstanding the complexity of the GGH modulationinduced changes in folate and antifolate accumulation and metabolism, the potential role of GGH modulation in 5FU- and MTX-based cancer chemotherapy warrants further investigation.

\section{ACKNOWLEDGEMENTS}

Funding was provided by the Canadian Institutes of Health Research (grant number 14126 to YIK).

\section{CONFLICT OF INTEREST}

The authors declare no conflict of interest.

\section{REFERENCES}

Aghi M, Kramm CM, Breakefield XO (1999) Folylpolyglutamyl synthetase gene transfer and glioma antifolate sensitivity in culture and in vivo. J Natl Cancer Inst 91(14): 1233-1241.

Alabaster O, Vonderhaar BK, Shafie SM (1981) Metabolic modification by insulin enhances methotrexate cytotoxicity in MCF-7 human breast cancer cells. Eur J Cancer Clin Oncol 17(11): 1223-1228.

Backus HH, Pinedo HM, Wouters D, Padron JM, Molders N, van Der Wilt CL, van Groeningen CJ, Jansen G, Peters GJ (2000) Folate depletion increases sensitivity of solid tumor cell lines to 5-fluorouracil and antifolates. Int J Cancer 87(6): 771-778.

Bailey RL, Mills JL, Yetley EA, Gahche JJ, Pfeiffer CM, Dwyer JT, Dodd KW, Sempos CT, Betz JM, Picciano MF (2010) Unmetabolized serum folic acid and its relation to folic acid intake from diet and supplements in a nationally representative sample of adults aged $>$ or $=60 \mathrm{y}$ in the United States. Am J Clin Nutr 92(2): 383-389.

Bonaa KH, Njolstad I, Ueland PM, Schirmer H, Tverdal A, Steigen T, Wang H, Nordrehaug JE, Arnesen E, Rasmussen K (2006) Homocysteine lowering and cardiovascular events after acute myocardial infarction. New Engl J Med 354(15): 1578-1588.

Bras-Goncalves RA, Rosty C, Laurent-Puig P, Soulie P, Dutrillaux B, Poupon MF (2000) Sensitivity to CPT-11 of xenografted human colorectal cancers as a function of microsatellite instability and p53 status. Br J Cancer 82(4): 913-923.

Bruce WR, Cirocco M, Giacca A, Kim YI, Marcon N, Minkin S (2005) A pilot randomised controlled trial to reduce colorectal cancer risk markers associated with B-vitamin deficiency, insulin resistance and colonic inflammation. Br J Cancer 93(6): 639-646.

Buroker TR, O'Connell MJ, Wieand HS, Krook JE, Gerstner JB, Mailliard JA, Schaefer PL, Levitt R, Kardinal CG, Gesme Jr DH (1994) Randomized comparison of two schedules of fluorouracil and leucovorin in the treatment of advanced colorectal cancer. J Clin Oncol 12(1): 14-20.

Cheng Q, Wu B, Kager L, Panetta JC, Zheng J, Pui CH, Relling MV, Evans WE (2004) A substrate specific functional polymorphism of human gammaglutamyl hydrolase alters catalytic activity and methotrexate polyglutamate accumulation in acute lymphoblastic leukaemia cells. Pharmacogenetics 14(8): 557-567.

Cheradame S, Etienne MC, Chazal M, Guillot T, Fischel JL, Formento P, Milano G (1997) Relevance of tumoral folylpolyglutamate synthetase and reduced folates for optimal 5-fluorouracil efficacy: experimental data. Eur J Cancer 33(6): 950-959.

Cho RC, Cole PD, Sohn KJ, Gaisano G, Croxford R, Kamen BA, Kim YI (2007) Effects of folate and folylpolyglutamyl synthase modulation on chemosensitivity of breast cancer cells. Mol Cancer Ther 6(11): 2909-2920. 
Cole PD, Kamen BA, Gorlick R, Banerjee D, Smith AK, Magill E, Bertino JR (2001) Effects of overexpression of gamma-Glutamyl hydrolase on methotrexate metabolism and resistance. Cancer Res 61(11): 4599-4604.

Dervieux T, Kremer J, Lein DO, Capps R, Barham R, Meyer G, Smith K, Caldwell J, Furst DE (2004) Contribution of common polymorphisms in reduced folate carrier and gamma-glutamylhydrolase to methotrexate polyglutamate levels in patients with rheumatoid arthritis. Pharmacogenetics 14(11): 733-739.

Draper NR, Smith H (1981) Applied Regression Analysis. 2nd edn, John Wiley \& Sons: New York.

Ebbing M, Bleie O, Ueland PM, Nordrehaug JE, Nilsen DW, Vollset SE, Refsum H, Pedersen EK, Nygard O (2008) Mortality and cardiovascular events in patients treated with homocysteine-lowering B vitamins after coronary angiography: a randomized controlled trial. JAMA 300(7): 795-804.

Galivan J, Ryan TJ, Chave K, Rhee M, Yao R, Yin D (2000) Glutamyl hydrolase. pharmacological role and enzymatic characterization. Pharmacol Ther 85(3): 207-215.

Hayashi H, Fujimaki C, Daimon T, Tsuboi S, Matsuyama T, Itoh K (2009) Genetic polymorphisms in folate pathway enzymes as a possible marker for predicting the outcome of methotrexate therapy in Japanese patients with rheumatoid arthritis. J Clin Pharm Ther 34(3): 355-361.

Jekic B, Lukovic L, Bunjevacki V, Milic V, Novakovic I, Damnjanovic T, Milasin J, Popovic B, Maksimovic N, Damjanov N, Radunovic G, Kovacevic L, Krajinovic M (2013) Association of the TYMS 3G/3G genotype with poor response and GGH 354GG genotype with the bone marrow toxicity of the methotrexate in RA patients. Eur J Clin Pharmacol 69(3): 377-383.

Kalmbach RD, Choumenkovitch SF, Troen AM, D'Agostino R, Jacques PF, Selhub J (2008) Circulating folic acid in plasma: relation to folic acid fortification. Am J Clin Nutr 88(3): 763-768.

Kamen B (1997) Folate and antifolate pharmacology. Semin Oncol 24(5 Suppl 18): S18-30-S18-39.

Kennedy DG, Clarke R, van den Berg HW, Murphy RF (1983) The kinetics of methotrexate polyglutamate formation and efflux in a human breast cancer cell line (MDA.MB.436): the effect of insulin. Biochem Pharmacol 32(1): 41-46.

Kim K, Kang SB, Chung HH, Kim JW, Park NH, Song YS (2008) XRCC1 arginine194tryptophan and GGH-401cytosine/thymine polymorphisms are associated with response to platinum-based neoadjuvant chemotherapy in cervical cancer. Gynecol Oncol 111(3): 509-515.

Koomdee N, Hongeng S, Apibal S, Pakakasama S (2012) Association between polymorphisms of dihydrofolate reductase and gamma glutamyl hydrolase genes and toxicity of high dose methotrexate in children with acute lymphoblastic leukemia. Asian Pac J Cancer Prev 13(7): 3461-3464.

Li WW, Waltham M, Tong W, Schweitzer BI, Bertino JR (1993) Increased activity of gamma-glutamyl hydrolase in human sarcoma cell lines: a novel mechanism of intrinsic resistance to methotrexate (MTX). Adv Exp Med Biol 338: 635-638.

Liani E, Rothem L, Bunni MA, Smith CA, Jansen G, Assaraf YG (2003) Loss of folylpoly-gamma-glutamate synthetase activity is a dominant mechanism of resistance to polyglutamylation-dependent novel antifolates in multiple human leukemia sublines. Int J Cancer 103(5): 587-599.

Llombart-Cussac A, Martin M, Harbeck N, Anghel RM, Eniu AE, Verrill MW, Neven P, De Greve J, Melemed AS, Clark R, Simms L, Kaiser CJ, Ma D (2007) A randomized, double-blind, phase II study of two doses of pemetrexed as first-line chemotherapy for advanced breast cancer. Clin Cancer Res 13(12): 3652-3659.

Longley DB, Harkin DP, Johnston PG (2003) 5-fluorouracil: mechanisms of action and clinical strategies. Nat Rev Cancer 3(5): 330-338.

Mauritz R, Peters GJ, Priest DG, Assaraf YG, Drori S, Kathmann I, Noordhuis P, Bunni MA, Rosowsky A, Schornagel JH, Pinedo HM, Jansen G (2002) Multiple mechanisms of resistance to methotrexate and novel antifolates in human CCRF-CEM leukemia cells and their implications for folate homeostasis. Biochem Pharmacol 63(2): 105-115.

McCloskey DE, McGuire JJ, Russell CA, Rowan BG, Bertino JR, Pizzorno G, Mini E (1991) Decreased folylpolyglutamate synthetase activity as a mechanism of methotrexate resistance in CCRF-CEM human leukemia sublines. J Biol Chem 266(10): 6181-6187.

Moran RG (1999) Roles of folylpoly-gamma-glutamate synthetase in therapeutics with tetrahydrofolate antimetabolites: an overview. Semin Oncol 26(2 Suppl 6): 24-32.
Nakajima TE, Yamada Y, Shimoda T, Matsubara J, Kato K, Hamaguchi T, Shimada Y, Okayama Y, Oka T, Shirao K (2008) Combination of O6methylguanine-DNA methyltransferase and thymidylate synthase for the prediction of fluoropyrimidine efficacy. EurJ Cancer 44(3): 400-407.

Nakamura A, Hayashi K, Nakajima G, Kamikozuru H, Okuyama R, Kuramochi H, Hatori T, Yamamoto M (2011) Impact of dihydropyrimidine dehydrogenase and gamma-glutamyl hydrolase on the outcomes of patients treated with gemcitabine or S-1 as adjuvant chemotherapy for advanced pancreatic cancer. Exp Ther Med 2(6): 1097-1103.

Owen SA, Hider SL, Martin P, Bruce IN, Barton A, Thomson W (2012) Genetic polymorphisms in key methotrexate pathway genes are associated with response to treatment in rheumatoid arthritis patients. Pharmacogenomics J 13: 227-234.

Panetta JC, Wall A, Pui CH, Relling MV, Evans WE (2002a) Methotrexate intracellular disposition in acute lymphoblastic leukemia: a mathematical model of gamma-glutamyl hydrolase activity. Clin Cancer Res 8(7): 2423-2429.

Panetta JC, Yanishevski Y, Pui CH, Sandlund JT, Rubnitz J, Rivera GK, Ribeiro R, Evans WE, Relling MV (2002b) A mathematical model of in vivo methotrexate accumulation in acute lymphoblastic leukemia. Cancer Chemother Pharmacol 50(5): 419-428.

Peters GJ, Laurensse E, Leyva A, Pinedo HM (1987) Purine nucleosides as cell-specific modulators of 5-fluorouracil metabolism and cytotoxicity. Eur J Cancer Clin Oncol 23(12): 1869-1881.

Peters GJ, Wets M, Keepers YP, Oskam R, van Ark-Otte J, Noordhuis P, Smid K, Pinedo HM (1993) Transformation of mouse fibroblasts with the oncogenes $\mathrm{H}$-ras OR trk is associated with pronounced changes in drug sensitivity and metabolism. Int J Cancer 54(3): 450-455.

Pfeiffer CM, Hughes JP, Lacher DA, Bailey RL, Berry RJ, Zhang M, Yetley EA, Rader JI, Sempos CT, Johnson CL (2012) Estimation of trends in serum and RBC folate in the U.S. population from pre- to postfortification using assay-adjusted data from the NHANES 1988-2010. J Nutr 142(5): 886-893.

Pizzorno G, Mini E, Coronnello M, McGuire JJ, Moroson BA, Cashmore AR, Dreyer RN, Lin JT, Mazzei T, Periti P, Berlino JR (1988) Impaired polyglutamylation of methotrexate as a cause of resistance in CCRF-CEM cells after short-term, high-dose treatment with this drug. Cancer Res 48(8): 2149-2155.

Pizzorno G, Moroson BA, Cashmore AR, Russello O, Mayer JR, Galivan J, Bunni MA, Priest DG, Beardsley GP (1995) Multifactorial resistance to 5,10-dideazatetrahydrofolic acid in cell lines derived from human lymphoblastic leukemia CCRF-CEM. Cancer Res 55(3): 566-573.

Radparvar S, Houghton PJ, Houghton JA (1989) Effect of polyglutamylation of 5,10-methylenetetrahydrofolate on the binding of 5-fluoro-2' deoxyuridylate to thymidylate synthase purified from a human colon adenocarcinoma xenograft. Biochem Pharmacol 38(2): 335-342.

Rhee MS, Wang Y, Nair MG, Galivan J (1993) Acquisition of resistance to antifolates caused by enhanced gamma-glutamyl hydrolase activity. Cancer Res 53(10 Suppl): 2227-2230.

Romanini A, Lin JT, Niedzwiecki D, Bunni M, Priest DG, Bertino JR (1991) Role of folylpolyglutamates in biochemical modulation of fluoropyrimidines by leucovorin. Cancer Res 51(3): 789-793.

Rots MG, Pieters R, Peters GJ, Noordhuis P, van Zantwijk CH, Kaspers GJ, Hahlen K, Creutzig U, Veerman AJ, Jansen G (1999) Role of folylpolyglutamate synthetase and folylpolyglutamate hydrolase in methotrexate accumulation and polyglutamylation in childhood leukemia. Blood 93(5): 1677-1683.

Roy K, Egan MG, Sirlin S, Sirotnak FM (1997) Posttranscriptionally mediated decreases in folylpolyglutamate synthetase gene expression in some folate analogue-resistant variants of the L1210 cell. Evidence for an altered cognate mRNA in the variants affecting the rate of de novo synthesis of the enzyme. J Biol Chem 272(11): 6903-6908.

Sakamoto E, Tsukioka S, Oie S, Kobunai T, Tsujimoto H, Sakamoto K, Okayama Y, Sugimoto Y, Oka T, Fukushima M (2008) Folylpolyglutamate synthase and gamma-glutamyl hydrolase regulate leucovorin-enhanced 5-fluorouracil anticancer activity. Biochem Biophys Res Commun 365(4): 801-807.

Schneider E, Ryan TJ (2006) Gamma-glutamyl hydrolase and drug resistance. Clin Chim Acta 374(1-2): 25-32.

Shane B (2010) Folate chemistry and metabolism. In Folate in Health and Disease, Bailey LB (ed) pp 1-24. CRC Press: Boca Raton, FL.

Shubbar E, Helou K, Kovacs A, Nemes S, Hajizadeh S, Enerback C, Einbeigi Z (2013) High levels of gamma-glutamyl hydrolase (GGH) are associated 
with poor prognosis and unfavorable clinical outcomes in invasive breast cancer. BMC Cancer 13: 47.

Sie KK, Medline A, van Weel J, Sohn KJ, Choi SW, Croxford R, Kim YI (2011) Effect of maternal and postweaning folic acid supplementation on colorectal cancer risk in the offspring. Gut 60(12): 1687-1694.

Silva IH, Nogueira-Silva C, Figueiredo T, Lombo L, Faustino I, Catarino R, Nogueira A, Pereira D, Medeiros R (2013) The impact of GGH -401C > T polymorphism on cisplatin-based chemoradiotherapy response and survival in cervical cancer. Gene 512(2): 247-250.

Skehan P, Storeng R, Scudiero D, Monks A, McMahon J, Vistica D, Warren JT, Bokesch H, Kenney S, Boyd MR (1990) New colorimetric cytotoxicity assay for anticancer-drug screening. J Natl Cancer Inst 82(13): 1107-1112.

Smit EF, Socinski MA, Mullaney BP, Myrand SP, Scagliotti GV, Lorigan P, Reck M, Ciuleanu T, von Pawel J, Karaseva NA, Szczesna A, Ohannesian D, Powell E, Hozak RR, Hong S, Guba SC, Thatcher N (2012) Biomarker analysis in a phase III study of pemetrexed-carboplatin versus etoposidecarboplatin in chemonaive patients with extensive-stage small-cell lung cancer. Ann Oncol 23(7): 1723-1729.

Sohn KJ, Croxford R, Yates Z, Lucock M, Kim YI (2004a) Effect of the methylenetetrahydrofolate reductase C677T polymorphism on chemosensitivity of colon and breast cancer cells to 5-fluorouracil and methotrexate. J Natl Cancer Inst 96(2): 134-144.

Sohn KJ, Smirnakis F, Moskovitz DN, Novakovic P, Yates Z, Lucock M, Croxford R, Kim YI (2004b) Effects of folylpolyglutamate synthetase modulation on chemosensitivity of colon cancer cells to 5 -fluorouracil and methotrexate. Gut 53(12): 1825-1831.

Song J, Sohn KJ, Medline A, Ash C, Gallinger S, Kim YI (2000) Chemopreventive effects of dietary folate on intestinal polyps in Apc + / - Msh2 - / - mice. Cancer Res 60(12): 3191-3199.

van der Straaten RJ, Wessels JA, De Vries-Bouwstra JK, Goekoop-Ruiterman YP, Allaart CF, Bogaartz J, Tiller M, Huizinga TW, Guchelaar HJ (2007) Exploratory analysis of four polymorphisms in human GGH and FPGS genes and their effect in methotrexate-treated rheumatoid arthritis patients. Pharmacogenomics 8(2): 141-150.

Waltham MC, Li WW, Gritsman H, Tong WP, Bertino JR (1997) gammaGlutamyl hydrolase from human sarcoma HT-1080 cells: characterization and inhibition by glutamine antagonists. Mol Pharmacol 51(5): 825-832.

Wang FS, Aschele C, Sobrero A, Chang YM, Bertino JR (1993) Decreased folylpolyglutamate synthetase expression: a novel mechanism of fluorouracil resistance. Cancer Res 53(16): 3677-3680.

Yanagimachi M, Naruto T, Hara T, Kikuchi M, Hara R, Miyamae T, Imagawa T, Mori M, Kaneko T, Morita S, Goto H, Yokota S (2011) Influence of polymorphisms within the methotrexate pathway genes on the toxicity and efficacy of methotrexate in patients with juvenile idiopathic arthritis. Br J Clin Pharmacol 71(2): 237-243.

Yao R, Rhee MS, Galivan J (1995) Effects of gamma-glutamyl hydrolase on folyl and antifolylpolyglutamates in cultured H35 hepatoma cells. Mol Pharmacol 48(3): 505-511.

Yao R, Schneider E, Ryan TJ, Galivan J (1996) Human gamma-glutamyl hydrolase: cloning and characterization of the enzyme expressed in vitro. Proc Natl Acad Sci USA 93(19): 10134-10138.

Zhao R, Gao F, Goldman ID (2001) Marked suppression of the activity of some, but not all, antifolate compounds by augmentation of folate cofactor pools within tumor cells. Biochem Pharmacol 61(7): $857-865$.

Zhao R, Titus S, Gao F, Moran RG, Goldman ID (2000) Molecular analysis of murine leukemia cell lines resistant to 5, 10-dideazatetrahydrofolate identifies several amino acids critical to the function of folylpolyglutamate synthetase. J Biol Chem 275(34): 26599-26606.

This work is published under the standard license to publish agreement. After 12 months the work will become freely available and the license terms will switch to a Creative Commons AttributionNonCommercial-Share Alike 3.0 Unported License.

Supplementary Information accompanies this paper on British Journal of Cancer website (http://www.nature.com/bjc) 